\title{
Cerámica y Vidrio

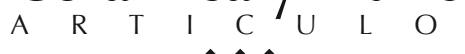

\section{Influencia de los tratamientos mecánicos y térmicos en materias primas que contienen pirofilita}

\author{
P.J. SÁNCHEZ SOTO, M.C. JIMÉNEZ DE HARO, J. PASCUAL COSP*, M. RAIGÓN PICHARDO** Y J.L. PÉREZ RODRíGUEZ \\ Instituto de Ciencia de Materiales de Sevilla, C.S.I.C. Universidad de Sevilla. 41092 Sevila. \\ * Departamento de Ingeniería Civil, de Materiales y Fabricación, E.T.S.Ingeniería Industrial, Universidad de Málaga. 29013 Malaga \\ ** Refractarios Alfran S.A. 41500-Alcalá de Guadaira, Sevilla.
}

En el presente trabajo se exponen y discuten resultados obtenidos en el estudio de la influencia de tratamientos térmicos, tratamientos mecánicos por molienda en seco, y su combinación, en materias primas que contienen pirofilita. En primer lugar, se estudia la influencia del tratamiento térmico en lo que respecta al desarrollo y evolución de las fases cristalinas (mullita y cristobalita) a partir de pirofilita deshidroxilada. Estos resultados se toman como base para analizar lo que ocurre en una mezcla natural de pirofilita con caolinita y mica (sericita) sometida a tratamientos térmicos. Las materias primas que contienen pirofilita se han alterado artificialmente en el laboratorio por modificaciones inducidas mediante tratamientos mecánicos por molienda en seco. Se pone de manifiesto que el aumento de la superficie específica y la reducción del tamaño de partícula se logra por medio del proceso de molienda, pero además se producen varios efectos en la estructura y propiedades del sólido sometido a este tratamiento, esto es, se inducen reacciones mecanoquímicas debido al aumento de reactividad en el sistema. Entre éstas, destaca el proceso de reaglomeración que ocurre por encima de un límite determinado de tiempo. La molienda, en general, conduce a una progresiva destrucción de la estructura original de los silicatos laminares presentes, pero con preferencia siguiendo el eje $c$. Este tratamiento mecánico favorece el aumento de reactividad dando lugar a que la formación de las fases cristalinas mullita y cristobalita se produzca a temperaturas más bajas que en las materias primas sin moler, lo que incide en el ahorro energético. Los resultados obtenidos se comparan y discuten teniendo en cuenta las estructuras cristalinas de pirofilita y caolinita, así como lo que sucede en la transformación térmica de caolinita a mullita y en el proceso de tratamiento mecánico de caolinita, debido a que este silicato se encuentra presente en estas materias primas naturales junto a la propia pirofilita.

Palabras clave: pirofilita, mullita, cristobalita, sericita, caolinita, tratamientos mecánicos, tratamientos térmicos.

\section{Influence of mechanical and thermal treatments on raw materials containing pyrophyllite}

In the present work results obtained in a study on the influence of thermal, mechanical by dry grinding, and their combination, in raw materials containing pyrophyllite, are discussed. First of all, it is studied the influence of thermal treatment concerning the development and evolution of crystalline phases (mullite and cristobalite) from dehydroxylated pyrophyllite. On the basis of these results, it is analyzed what happens in a natural raw mixture of pyrophyllite with kaolinite and mica (sericite) submitted to thermal treatments. The raw pyrophyllite materials are altered under laboratory conditions using mechanical treatments by dry grinding. It is noted that the increase of surface area and particle size reduction is produced by grinding, but other effects are produced on the structure and properties of the solid submitted to grinding. In general, grinding leads to a progressive destruction of the original crystal structure of the present layered silicates, but it is preferentially produced along the " $c$ " axis. In other words, mechanochemical reactions are induced by dry grinding due to the increase of reactivity of the system. Between these reactions, it is enhanced the reagglomeration process that occurs above a determinate limit of grinding time. The grinding treatment can be combined with a subsequent thermal treatment that enhances the increase of reactivity, producing the formation of crystalline phases (mullite and cristobalite) at lower temperatures that in unground samples with energy saving. The results are compared taking into account the crystal structures of both kaolinite and pyrophyllite, the thermal transformation of kaolinite to mullite, and the process of grinding kaolinite because this layer silicate is present in the raw materials containing pyrophyllite.

Key works: pyrophyllite, mullite, cristobalite, sericite, kaolinite, mechanical treatments, mechanical thermal treatments.

\section{INTRODUCCION}

En un trabajo reciente de revisión sobre pirofilita $(1,2)$ se han expuesto y descrito las investigaciones realizadas sobre la estructura de este filosilicato, sus características generales y propiedades más importantes, su síntesis en el laboratorio y la formación de soluciones sólidas. En particular, se revisaron y discutieron las investigaciones realizadas sobre sus propiedades térmicas características en lo que concierne a los procesos

\section{INTRODUCTION}

In a recent review on pyrophyllite $(1,2)$, it was described the research carried out on the structure of this layer silicate, its general characteristics and most important properties, laboratory synthesis and formation of solid solutions. In particular, it was revised and discussed the research carried out on its characteristic thermal properties concerning the processes of dehydroxilation, rehydroxilation and formation of high-tem- 
de deshidroxilación, rehidroxilación y formación de fases de alta temperatura (mullita y cristobalita), aspectos de elevado interés por su aplicación como materia prima cerámica (2). Asimismo, se han indicado los principales yacimientos mundiales de pirofilita, los datos de producción disponibles y las investigaciones realizadas en nuestro país sobre prospección y caracterización de materias primas con pirofilita, los cuales presentan marcado interés aplicado. Existen varios yacimientos de importancia distribuidos por todo nuestro planeta. De ellos, los más importantes se encuentran en Japón, Corea del Sur y EE.UU., con más del $90 \%$ de la producción mundial. En España existe pirofilita, pero aparece mezclada con otros minerales, como son las asociaciones caolinita-mica(sericita)-pirofilita, fundamentalmente en Extremadura, Córdoba y Ciudad Real formando parte de las denominadas "pizarras alumínicas" con o sin cuarzo (3-6).

En el presente trabajo se exponen y discuten resultados obtenidos en el estudio de la influencia de tratamientos térmicos, tratamientos mecánicos por molienda, y su combinación, en materias primas que contienen pirofilita. Estas investigaciones han sido llevadas a cabo y se continuan en la actualidad en lo que respecta al estudio sobre la formación de mullita. Se pondrá de manifiesto que la reducción del tamaño de partícula de materias primas que contienen pirofilita se logra por medio del proceso de molienda, pero además se pueden producir varios efectos en la estructura y propiedades del sólido sometido a este tratamiento e inducir reacciones químicas debido al aumento de reactividad en el sistema, englobándose en lo que se ha denominado mecanoquímica $(7,8)$. Un posterior tratamiento térmico acentúa aún más el aumento de reactividad que se ha producido. Estos resultados se comparan teniendo en cuenta las estructuras cristalinas de pirofilita y caolinita, así como lo que sucede en la transformación térmica de caolinita a mullita y en el proceso de tratamiento mecánico de caolinita, silicato presente en estas materias primas naturales, además de la mica (sericita) y pirofilita.

\section{MATERIALES Y METODOS EXPERIMENTALES}

\subsection{Materiales estudiados}

Se utilizó pirofilita compacta de EE.UU. (Hillsboro, North Carolina) suministrada por Ward's N.S. (Rochester, New York). La muestra original (PyH) se sometió a una molienda previa y tamizado por debajo de $50 \mu \mathrm{m}$. La composición mineralógica de esta muestra es de $90 \%$ en peso de pirofilita, acompañada de cantidades menores de caolinita (5\%) y mica (5\%), encontrándose exenta de cuarzo. El análisis químico de estas muestras se presenta en la Tabla 1. Asimismo, se utilizó una muestra representativa de pizarra alumínica con pirofilita procedente de uno de los yacimientos de Zalamea de la Serena (Badajoz), previamente descrito $(5,6)$ y denominada ZS. Esta pizarra es de color grisáceo, muy blanda, esquistosa y untuosa al tacto. Se empleó la fracción menor de $63 \mu \mathrm{m}$ previa dispersión en húmedo, separación de las fracciones más gruesas y secado a $110{ }^{\circ} \mathrm{C}$. La composición mineralógica de la misma es de $40 \%$ de pirofilita, $30 \%$ de caolinita y $30 \%$ de mica de grano fino o sericita. El análisis químico se da en la Tabla 1. La presencia de micas se confirma por los alcalinos presentes, fundamentalmente $\mathrm{K}_{2} \mathrm{O}$, comprobándose también que existen óxidos de hierro y rutilo en baja proporción que no se detectan, aparentemente, en el análisis mineralógico al ser minoritarios. perature phases (mullite and cristobalite). These are aspects of great interest due to the application of pyrophyllite as a raw ceramic material (2). The main world deposits were indicated, as well as the available production data, and the research performed in our country on mining and characterization of raw materials containing pyrophyllite of marked applied interest.

There are several important pyrophyllite deposits in the world. Between them, the most important ones are settled in Japan, South Korea and USA, with more than $90 \%$ world production. In Spain there is also pyrophyllite deposits, but frequently appears with other minerals in association, such as kaolinite-mica(sericite)-pyrophyllite, mainly in Extremadura, Cordoba and Ciudad Real forming part of so-called "aluminium shales", with or without quartz (3-6).

In the present work, results obtained in studies on the influence of thermal, mechanical by dry grinding, and their combination, in raw materials containing pyrophyllite, are discussed. These investigations have been carrried out and continued actually concerning the study of mullite formation. It is remarked that the increase of surface area and particle size reduction is produced by grinding, but other effects are produced on the structure and properties of the solid submitted to grinding. In other words, mechanochemical reactions $(7,8)$ are induced by dry grinding due to the increase of reactivity of the system. A subsequent thermal treatment enhances the increase of reactivity. The results are compared taking into account the thermal transformation of kaolinite to mullite, the crystal structures of both kaolinite and pyrophyllite, and the process of grinding kaolinite, because this layer silicate is present in the natural raw materials containing pyrophyllite besides of mica (sericite).

\section{MATERIALS AND EXPERIMENTAL METHODS}

\subsection{Materials}

Raw pyrophyllite (Hillsboro, North Carolina, USA) from Ward's N.S. (Rochester, New York) was crushed, ligthly ground and sieved to pass $50 \mu \mathrm{m}$. The mineralogical composition of this sample $(\mathrm{PyH})$ showed pyrophyllite $90 \mathrm{wt} \%$, and minor amounts of kaolinite ( $5 \mathrm{wt} \%)$ and mica ( $5 \mathrm{wt} \%)$, with no quartz present. The chemical analysis is included in Table 1. A representative sample of aluminium shale with pyrophyllite from one deposit in Zalamea de la Serena (Badajoz, Extremadura, Spain), previously described $(5,6)$ was also used.

TABLA 1.- DATOS DE ANÁLISIS QUÚMICO DE LAS MUESTRAS ESTUDIADAS (PIROFILITAS PYH Y ZS).

TABLE 1.- CHEMICAL ANALYSIS RESULTS OF PYROPHYLLITE SAMPLES PYH AND ZS

\begin{tabular}{|c|c|c|}
\hline wt $\%$ & PyH & ZS \\
\hline $\mathrm{SiO}_{2}$ & 66.42 & 52.19 \\
$\mathrm{Al}_{2} \mathrm{O}_{3}$ & 27.31 & 33.89 \\
$\mathrm{Fe}_{2} \mathrm{O}_{3}$ & 0.20 & 1.77 \\
$\mathrm{TiO}_{2}$ & 0.10 & 1.38 \\
$\mathrm{MgO}$ & 0.01 & 0.22 \\
$\mathrm{CaO}$ & 0.09 & 0.45 \\
$\mathrm{Na}_{2} \mathrm{O}$ & 0.10 & 0.67 \\
$\mathrm{~K}_{2} \mathrm{O}$ & 0.24 & 2.04 \\
$\mathrm{LOI}$ & 5.41 & 8.01 \\
\hline
\end{tabular}

LOI = "loss on ignition": weight loss after thermal treatment of the samples at $1000{ }^{\circ} \mathrm{C}$ for 1 hour 


\subsection{Métodos experimentales}

Para la reducción previa de pirofilita compacta se empleó un molino de anillos Herzog HSM-100, tamizando el polvo repetidamente hasta pasar por el tamiz de $50 \mu \mathrm{m}$. Las experiencias de molienda se llevaron a cabo empleando un molino planetario de bolas (Modelo S-1, Retsch) de $250 \mathrm{~mL}$ de capacidad, a una velocidad de $250 \mathrm{rpm}$. Los diagramas de rayos X (DRX) se obtuvieron utilizando un difractómetro Siemens modelo D-500 con radiación $\mathrm{CuK} \alpha$ y velocidad de goniómetro de $1^{\circ} 2 \Theta$ por minuto. La superficie específica se determinó mediante adsorción de nitrógeno (método del punto b) empleando un equipo automático Micromeritics modelo 2200 A, previa desgasificación del polvo durante 2 horas a $150{ }^{\circ} \mathrm{C}$.

El análisis térmico diferencial y termogravimétrico (ATDTG) se realizó empleando un equipo Rigaku Thermoflex PTC$10 \mathrm{~A}$ a una velocidad de calentamiento de $12{ }^{\circ} \mathrm{C}$ por minuto. Asimismo, se prepararon probetas mediante prensado uniaxial a $150 \mathrm{MPa}$ con un $5 \%$ de humedad que una vez secas se sometieron a tratamientos térmicos a distintas temperaturas durante un tiempo máximo de 2 horas. Una vez enfriadas las probetas, se determinó la capacidad de absorción de agua teniendo en cuenta las normas UNE de refractarios.

\section{RESULTADOS OBTENIDOS Y DISCUSION}

\subsection{Influencia de tratamientos térmicos}

En la Figura 1 se presentan las curvas de análisis térmico ATD-TG correspondientes a las muestras de pirofilita PyH y ZS. En la curva de ATD de pirofilita pura $(\mathrm{PyH})$ se observa un ancho efecto endotérmico en la región entre 600 y $800{ }^{\circ} \mathrm{C}$, correspondiente también al mayor intervalo de pérdida de peso en el diagrama TG. Aunque ha existido cierta controversia en el estudio térmico de pirofilitas debido a la variabilidad observada (1), se puede considerar que esta curva es característica de una pirofilita normal. Asimismo, se detectan efectos térmicos exotérmicos de baja intensidad a $1000{ }^{\circ} \mathrm{C}$, asociado a la impureza de caolinita presente (9), y otros a 1215 y $1325^{\circ} \mathrm{C}$. Se comprobó que mediante un tratamiento ácido previo (10) de la muestra se eliminaba la caolinita y daba como resultado que no se detectara el primer efecto exotérmico. En la muestra ZS se comprueba la presencia de pirofilita por ATD y se detecta caolinita por su efectos térmicos característicos a $560{ }^{\circ} \mathrm{C}$ (endotérmico), correspondiente a su deshidroxilación, y $985^{\circ} \mathrm{C}$ (exotérmico) asociado a la formación de premullita $(11,12)$, seguido de un exotérmico menos intenso a $1150{ }^{\circ} \mathrm{C}$. Otros efectos térmicos de menor intensidad en la curva de ATD se asocian a la pérdida de agua por deshidratación sobre 110 ${ }^{\circ} \mathrm{C}$ y a la procedente de óxidos de hierro en distintos estados de hidratación (sistema endo-exo a 200-400 ${ }^{\circ} \mathrm{C}$ ), según Mackenzie (13).

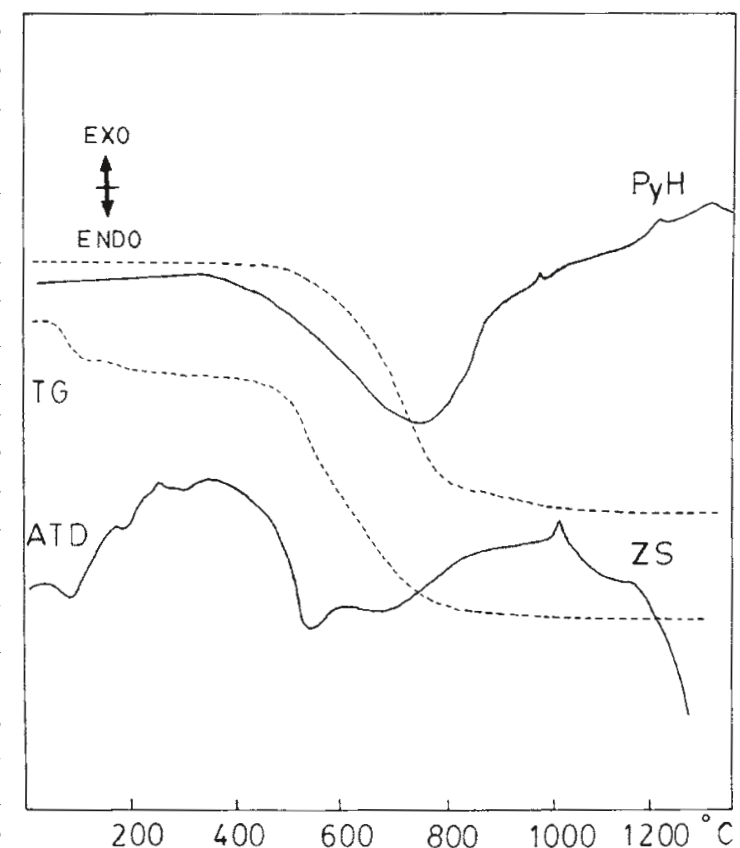

Figura 1.- Curvas de análisis térmico (ATD-TG) de las muestras de pirofilita PyH y ZS.

Figure 1.- Thermal analysis curves (DTA-TG) for pyrophyllite samples $\mathrm{PyH}$ and $\mathrm{ZS}$.
This sample (ZS) shows grey colour. It is very soft, with layered aspect and grease. The fraction of particle size under $63 \mu \mathrm{m}$ of this sample was selected after dispersion, wet sieving and obtention of free-agglomerated powders. The mineralogical composition of dried powders $\left(110^{\circ} \mathrm{C}\right)$, determined after X-ray diffraction analysis, showed $40 \mathrm{wt} \%$ pyrophyllite, $30 \mathrm{wt} \%$ kaolinite and $30 \mathrm{wt} \%$ mica (sericite). Table 1 shows the chemical analysis of these samples. The presence of mica is confirmed by the $\mathrm{K}_{2} \mathrm{O}$ content, with minor iron and titanium oxides also present.

\subsection{Experimental methods}

For a previous particle size reduction of pyrophyllite $\mathrm{PyH}$, a Herzog HSM-100 ring mill was used. The powder was repeteadly sieved to pass $50 \mu \mathrm{m}$ and used in that form. Dry grinding of samples was conducted in a planetary ball mill (Model S-1, Retsch, Haan, Germany) of $250 \mathrm{~mL}$, at a rate of 250 r.p.m. $X$-ray diffraction powder patterns (XRD) were obtained using a Siemens diffractometer model D-500, with nickel-filtered $\mathrm{CuK} \alpha$ radiation, at a goniometer speed of $1^{\circ} 2 \Theta$ per min. Specific surface areas (BET) were obtained with an automatic system Micromeritics model 2200 A by nitrogen adsorption (point $b$ method) at liquid nitrogen temperature. The powders were outgassed at $150{ }^{\circ} \mathrm{C}$ during 2 hours. Differential thermal analysis (DTA) and thermal gravimetric anlysis (TG) were obtained simultaneously in static air with a thermal analyzer (Rigaku Thermoflex PTC-10A, Tokyo, Japan) at a heating rate of $12{ }^{\circ} \mathrm{C}$ per min. Finally, samples pressed at $150 \mathrm{MPa}$ with $5 \mathrm{wt} \%$ of humidity were dried and thermally treated at several temperatures with a soaking time of 2 hours. After cooling, the water absorption capacity was determined by the Archimedes method taking into account the spanish refractories normative. 
Todos estos efectos en la curva de ATD de esta mezcla natural, salvo el exotérmico de caolinita, llevan asociados pérdidas de peso en el diagrama TG.

Por medio de la difracción de rayos $X$ (Fig. 2) se ha seguido la secuencia de desarrollo y evolución de las fases cristalinas con la temperatura en estas muestras, una vez sometidas a tratamientos térmicos en condiciones dinámicas de calentamiento (ATD-TG) hasta temperaturas previamente seleccionadas. En la muestra PyH (Fig. 2a) se detectan a $1050{ }^{\circ} \mathrm{C}$ líneas de difracción de pirofilita deshidroxilada cristalina que, a diferencia de la caolinita deshidroxilada (metacaolinita), no es amorfa a los rayos X (12). Se conoce que la fase pirofilita deshidroxilada persiste en un amplio intervalo de temperatura desde antes de $800{ }^{\circ} \mathrm{C}$ sin destruirse $(14 a, b, 15)$. Por descomposición térmica de la pirofilita deshidroxilada, se forma mullita a partir de $1200{ }^{\circ} \mathrm{C}$ que cristaliza a $1215^{\circ} \mathrm{C}$, ya con destrucción total de la fase deshidroxilada. Posteriormente cristaliza la fase cristobalita a $1325^{\circ} \mathrm{C}$ a partir de la sílice amorfa que se produce. Este proceso también se ha estudiado previamente por resonancia magnética nuclear de estado sólido de los núcleos Si-29 y Al-27 $(16,17)$.

En un trabajo anterior (17) se observó que en la pirofilita PyH tratada a $1100{ }^{\circ} \mathrm{C}$ durante 24 horas, se produce una disminución en la intensidad de los picos de la fase deshidroxilada, detectada desde $800{ }^{\circ} \mathrm{C}$, un aumento de fondo del difractograma centrado a $21^{\circ} 2 \Theta$ (pico de intensidad máximo de cristobalita) y la detección de picos de mullita. A $1150{ }^{\circ} \mathrm{C}$, también at 1215 and $1325^{\circ} \mathrm{C}$. Elimination of kaolinite impurity by acid treatment of the raw pyrophyllite $\mathrm{PyH}$ removed the peak at ca. $1000{ }^{\circ} \mathrm{C}$ from the DTA curve (10). In the ZS sample, it is observed the presence of pyrophyllite and kaolinite according to their thermal characteristic effects. These effects are produced at $560{ }^{\circ} \mathrm{C}$ (endothermic), associated to kaolinite dehydroxilation with formation of amorphous metakaolinite and important water weight loss, and $985{ }^{\circ} \mathrm{C}$ (exothermic), with no weight loss, associated to premullite formation from metakaolinite decomposition $(11,12)$. A weak exothermic DTA effect is also detected at $1150{ }^{\circ} \mathrm{C}$. Other weak thermal effects in the DTA curve of ZS sample are associated to heat evolution and weight loss by dehydration $\left(110{ }^{\circ} \mathrm{C}\right)$ and water weight loss from hydrated iron oxides (endo-exo system between 200-400 $\left.{ }^{\circ} \mathrm{C}\right)$, according to Mackenzie (13).

Based on XRD results (Fig. 2a,2b), it has been followed the sequence of development and evolution of crystalline phases in these pyrophyllite samples after thermal treatment under dynamic conditions (DTA-TG). In the PyH sample (Fig. 2a), it is deduced that pyrophyllite firstly dehydroxilate and forms dehydroxilated pyrophyllite detected at $1050{ }^{\circ} \mathrm{C}$, a crystalline phase which is not amorphous to X-rays, in contrast with kaolinite after dehydroxilation (metakaolinite). It is documented that dehydroxilated pyrophyllite persist from $800{ }^{\circ} \mathrm{C}$ to a broad temperature range without any destruction $(14 a, 14 b, 15)$, a remarkable difference with kaolinite after dehydroxilation (12). By thermal decomposition of dehydroxilated pyrophylli-
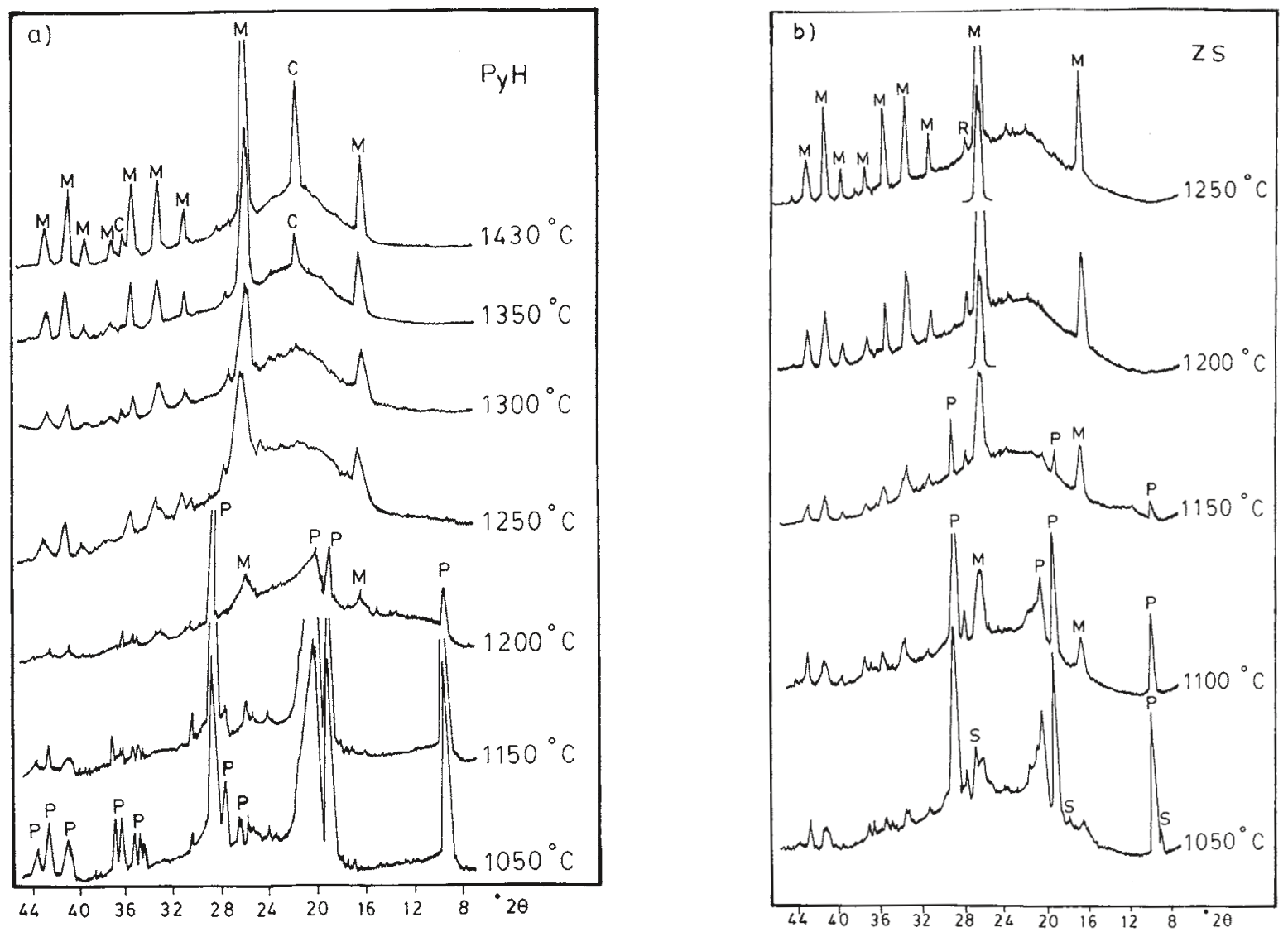

Figura 2.- Diagramas de difracción de rayos $\mathrm{X}$ de las muestras a) $\mathrm{PyH} \mathrm{y} \mathrm{b)} \mathrm{ZS} \mathrm{sometidas} \mathrm{a} \mathrm{distintos} \mathrm{tratamientos} \mathrm{térmicos.} \mathrm{P=} \mathrm{Pirofilita} \mathrm{deshi-}$ droxilada; $\mathrm{M}=$ Mullita; $\mathrm{C}=$ Cristobalita; $\mathrm{S}=$ Mica (Sericita) deshidroxilada; $\mathrm{R}=$ Rutilo.

Figure 2.- $\mathrm{XRD}$ diagrams of samples a) $\mathrm{PyH}$, and b) $\mathrm{ZS}$ after several thermal treatments. $\mathrm{P}=$ Dehydroxilated Pyrophyllite; $\mathrm{M}=\mathrm{Mullite} ; \mathrm{C}=$ Cristobalite; $\mathrm{S}=$ Dehydroxilated Mica (Sericite); $\mathrm{R}=$ Rutile. 
durante 24 horas, desaparece la pirofilita deshidroxilada y se aprecian mullita bien cristalizada y cristobalita, como ocurre también a $1250{ }^{\circ} \mathrm{C}$. De estos resultados se deduce que un tratamiento térmico prolongado favorece, pues, la formación de nuevas fases cristalinas a temperaturas más bajas, con destrucción de la estructura de pirofilita deshidroxilada, lo que indica la existencia de importantes efectos cinéticos en la descomposición térmica de pirofilita. Los resultados anteriormente descritos son de utilidad para la interpretación del proceso de descomposición térmica que experimenta la pirofilita ZS.

Los difractogramas de rayos $X$ de la pirofilita ZS (Fig. 2b) permiten observar la presencia a $1050{ }^{\circ} \mathrm{C}$ de pirofilita deshidroxilada, mullita de baja cristalinidad, así como indicios de mica deshidroxilada (sericita). En muestras de arcillas sericíticas se ha llegado a afirmar (3) la detección de bandas características de formación de un silicato alumínico y potásico, de fórmula $\mathrm{SiO}_{4} \mathrm{AlK}$. A la luz de los resultados del presente trabajo, estas bandas deben atribuirse a difracciones de la red cristalina de pirofilita deshidroxilada. Previamente, la mullita ha nucleado, como indicaba el intenso efecto exotérmico a 985 ${ }^{\circ} \mathrm{C}$ (Fig. 1). En el intervalo $1050-1200{ }^{\circ} \mathrm{C}$, la pirofilita deshidroxilada va desapareciendo progresivamente, aumentando la for- te, mullite is formed progressively from $1200^{\circ} \mathrm{C}$ with crystallization at $1215^{\circ} \mathrm{C}$ with destruction of dehydroxilated pyrophyllite. With subsequent heating, cristobalite crystallizes at 1325 ${ }^{\circ} \mathrm{C}$ from amorphous silica produced in the previous thermal decomposition. This process has been previously studied using 29-Si and 27-Al solid-state MAS-NMR spectroscopies $(16,17)$.

In a precedent work (17), it was observed that thermal treatment of pyrophyllite $\mathrm{PyH}$ at $1000{ }^{\circ} \mathrm{C}$ for 24 hours produced the diminution of the intensity of dehydroxilated phase, detected from $800{ }^{\circ} \mathrm{C}$, an important broad peak centered at $21^{\circ}$ $2 \Theta$ (maximum peak of cristobalite) and the detection of mullite $\mathrm{X}$-ray peaks whose intensities increase with the temperature of thermal treatment. After $1150{ }^{\circ} \mathrm{C}$ for 24 hours, the patterns of dehydroxilated pyrophyllite disappeared and well-crystallized mullite and cristobalite are identified, as occurs after $1250{ }^{\circ} \mathrm{C}$. From these results, it is clear that prolonged heating treatments favour the formation of the new crystalline phases at lower temperatures, indicating the existence of important kinetic effects in the thermal decomposition of pyrophyllite. The above results are usefull to make an interpretation on the thermal decomposition of pyrophyllite sample ZS.

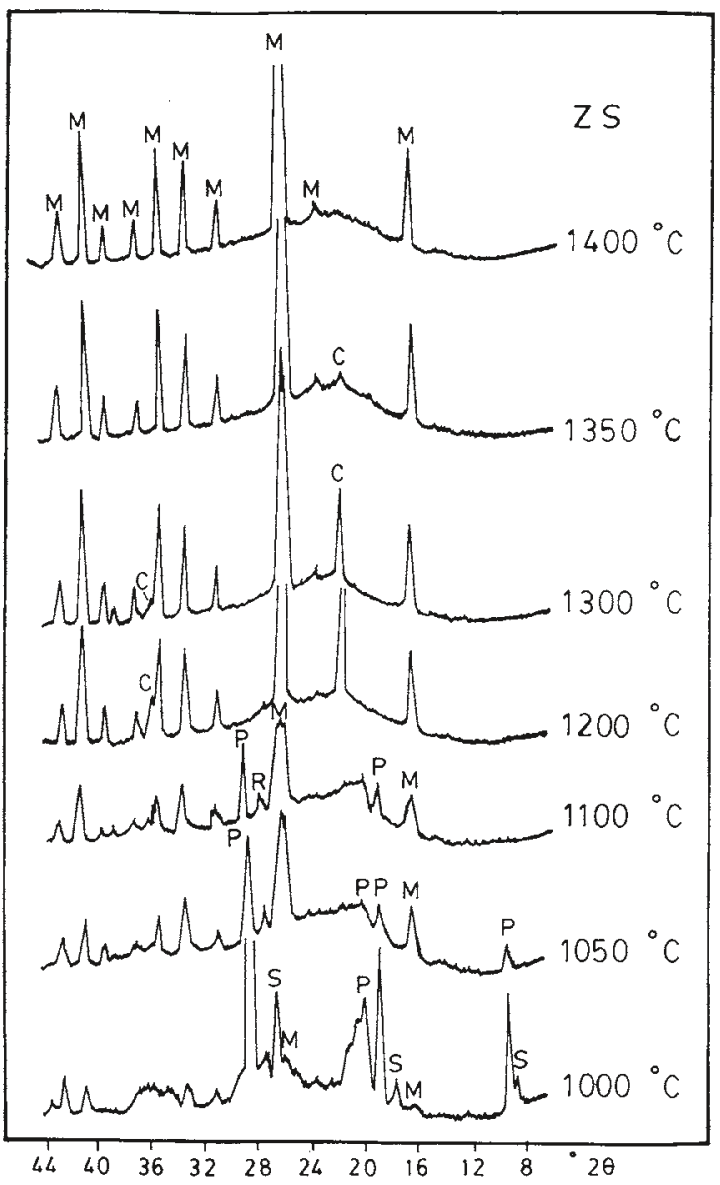

Figura 3.- Diagramas de difracción de rayos $\mathrm{X}$ de pirofilita ZS después de tratamiento isotermo de 2 horas a diversas temperaturas. $\mathrm{P}=$ Pirofilita deshidroxilada; $\mathrm{M}=$ Mullita $\mathrm{C}=$ Cristobalita $\mathrm{S}=\mathrm{Mica}$ (Sericita) deshidroxilada; $\mathrm{R}=$ Rutilo.

Figure 3.- XRD diagrams of sample ZS after isothermal treatment during 2 hours. $\mathrm{P}=$ Dehydroxilated Pyrophyllite; $\mathrm{M}=$ Mullite; $\mathrm{C}=$ Cristobalite; $\mathrm{S}=$ Dehydroxilated Mica (Sericite); $\mathrm{R}=$ Rutile.

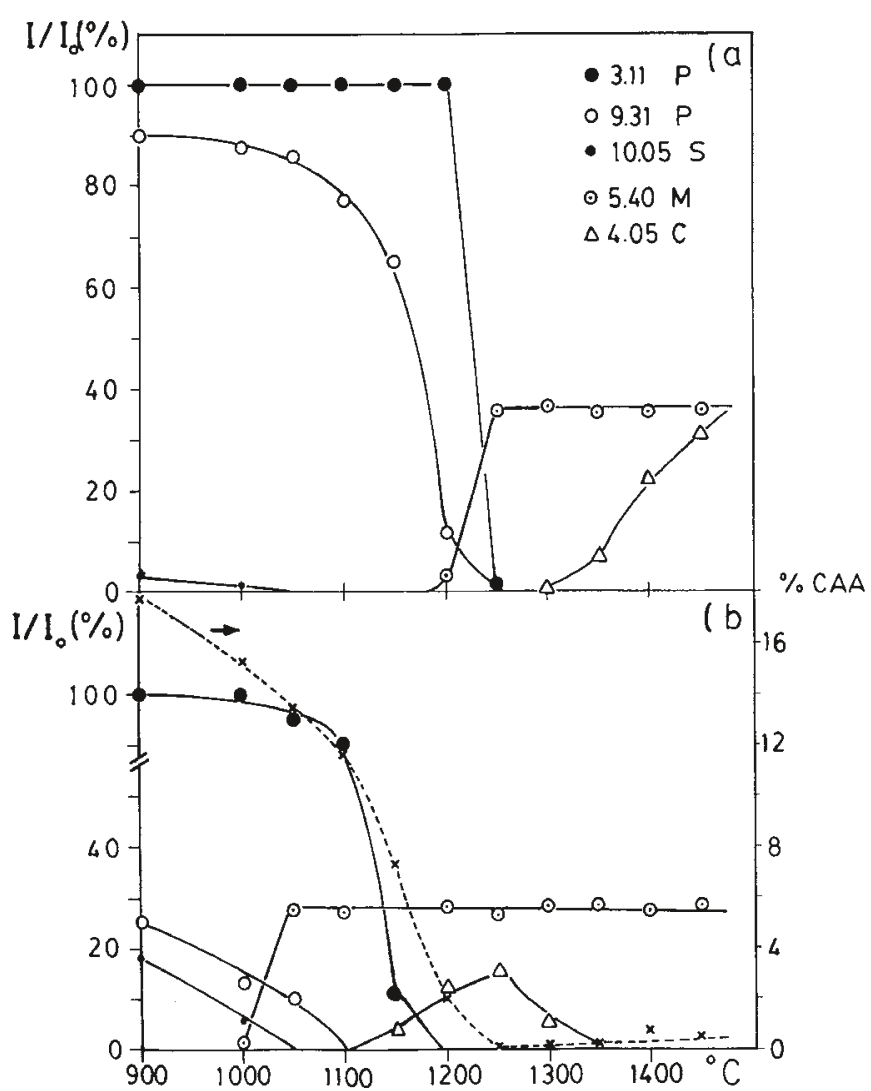

Figura 4.- Diagramas de desarrollo y evolución de fases cristalinas con la temperatura para las muestras de pirofilita (a) $\mathrm{PyH}$ y (b) ZS. Se dan los espaciados en A de las intensidades consideradas. $\mathrm{P}=$ Pirofilita deshidroxilada; $\mathrm{M}=$ Mullita; $\mathrm{C}=$ Cristobalita; $\mathrm{S}=$ Mica (Sericita) deshidroxilada.

Figure 4.- Diagrams of development and evolution of crystalline phases with temperature for pyrophyllite samples (a) $\mathrm{PyH}$, and (b) ZS. The d-spacings (in Angstroms) of X-ray peaks are indicated. $\mathrm{P}=$ Dehydroxilated Pyrophyllite; $\mathrm{M}=$ Mullite; $\mathrm{C}=$ Cristobalite; $\mathrm{S}=$ Dehydroxilated Mica (Sericite). 
mación y desarrollo de los cristales de mullita. La pirofilita deshidroxilada prácticamente no se detecta a $1200{ }^{\circ} \mathrm{C}$, cuando se ha producido el segundo efecto exotérmico de ATD atribuido a la cristalización de mullita (Fig. 1), ya que esta fase ha alcanzado mayor perfección cristalina a juzgar por la resolución del doblete característico de mullita (3,39-3,42 A) en el difractograma obtenido.

A $1250{ }^{\circ} \mathrm{C}$ sólo se encuentran presentes mullita y algo de rutilo (difracción a 3,25 A), inicialmente presente en la muestra (Tabla 1), así como una elevada cantidad de fase vítrea que se aprecia por el fondo del diagrama DRX (Fig. 2). A diferencia de lo que ocurre en la muestra $\mathrm{PyH}$, en el caso de la pirofilita ZS no se ha formado cristobalita por calentamiento dinámico hasta la máxima temperatura estudiada. Por último, el material se aprecia ya sinterizado después del ensayo, como podría deducirse, en principio, del aspecto de la curva de ATD a partir de $1200{ }^{\circ} \mathrm{C}$. Estos resultados son compatibles con el diagrama de equilibrio ternario de fases $\mathrm{SiO}_{2}-\mathrm{Al}_{2} \mathrm{O}_{3}-\mathrm{K}_{2} \mathrm{O}$ (E.F. Osborn and A. Muan, Phase Diagrams for Ceramists, Plate 5, The American Ceramic Society, 1960)(3), teniendo en cuenta la mayor cantidad de fase vítrea desarrollada en la pirofilita ZS y que la pirofilita deshidroxilada persiste en un intervalo de temperatura antes de su descomposición en mullita y cristobalita.

La Figura 3 muestra los diagramas DRX correspondientes a la pirofilita ZS sometida a tratamientos isotermos de 2 horas, que permiten estudiar el desarrollo y evolución de las fases cristalinas con la temperatura. Se observa la progresiva destrucción de las redes cristalinas de mica (sericita) y pirofilita, ambas fases deshidroxiladas, desde $1000{ }^{\circ} \mathrm{C}$, persistiendo esta última hasta los $1100{ }^{\circ} \mathrm{C}$ (difracción a 3,11 A). La nucleación de mullita se detecta a $1000^{\circ} \mathrm{C}$, posiblemente por descomposición térmica de la mica (sericita) y caolinita aumentando su perfección cristalina por encima de los $1050{ }^{\circ} \mathrm{C}$. Se detecta también rutilo (difracción más intensa a 3,23 A) que desaparece por encima de $1100^{\circ} \mathrm{C}$. La cristobalita se aprecia muy acusadamente a $1200^{\circ} \mathrm{C}$ (Fig.3). La cristobalita persiste hasta prácticamente desaparecer a $1350{ }^{\circ} \mathrm{C}$. En materias primas similares, arcillas sericíticas con pirofilita, no se ha llegado a observar cristobalita ni aún estando presente cuarzo inicialmente (3).

La Fig. 4 muestra, a efectos comparativos, los diagramas de desarrollo y evolución de las fases cristalinas con la temperatura para las pirofilitas $\mathrm{PyH}$ y $\mathrm{ZS}$, donde se han representado las intensidades relativas de espaciados característicos de rayos $X$ en función de las temperaturas de tratamiento. De este modo, se aprecia la progresiva destrucción de la mica (sericita) deshidroxilada y, principalmente, de la pirofilita deshidroxilada al aumentar la temperatura, así como la formación de mullita y cristobalita en ambas muestras. En el caso de la muestra ZS, la formación de ambas fases ocurre antes que en la $\mathrm{PyH}$. La cristobalita tendría su origen en una cristalización a partir de sílice amorfa segregada en la descomposición térmica de caolinita, a la que se une la que tiene su origen en la descomposición térmica de pirofilita deshidroxilada al aumentar la temperatura o el tiempo de tratamiento. La formación de mullita en la ZS posee un triple origen: a partir de la descomposición de caolinita (efecto exotérmico de ATD a $985^{\circ} \mathrm{C}$ ) y a partir de la descomposión de pirofilita y mica deshidroxiladas. Una vez formada persiste en el rango de temperaturas estudiado, a diferencia de la cristobalita que desaparece por encima de $1300{ }^{\circ} \mathrm{C}$. La formación de mullita por tratamiento térmico en este tipo de materias primas con pirofilita está favorecida por el pequeño tamaño de partículas de los silicatos presentes, su mezcla íntima y la acción de la mica (sericita) como fundente, todo lo cual acelera las reacciones de descomposición y
The XRD results of sample ZS (Fig. $2 b$ ) allow to observe dehydroxilated pyrophyllite at $1050^{\circ} \mathrm{C}$, low-crystalline mullite and dehydroxilated mica (sericite). In samples of sericite clays, it has been claimed (3) the detection of characteristic X-ray bands associated to a potassium and aluminium silicate formulated as $\mathrm{SiO}_{4} \mathrm{AlK}$. Taking into account the present results, these bands must be attributed to diffractions of the crystalline phase dehydroxilated pyrophyllite. Mullite nucleated when the sharp exothermic DTA effect at $985^{\circ} \mathrm{C}$ is detected (Fig. 1). In the temperature range $1050-1200{ }^{\circ} \mathrm{C}$, dehydroxilated pyrophyllite disappeared progressively with an increase of mullite X-ray intensities. Dehydroxilated pyrophyllite is not detected practically at $1200^{\circ} \mathrm{C}$, when the second exothermic DTA effect of mullite crystallization is produced (Fig. 1). Then, mullite is well-crystallized according to the resolution of the characteristic doublet at 3,39-3,42 A in the diffractogram.

After $1250{ }^{\circ} \mathrm{C}$, mullite and some rutile (3,25 A) are present, besides of a X-ray background associated to the presence of a glassy phase (Fig. 2). Rutile was associated to $\mathrm{TiO}_{2}$ checked by chemical analysis (Table 1). Cristobalite is not detected in ZS sample up to the maximum temperature studied, in contrast to $\mathrm{PyH}$ sample. It is interesting to note that the material sintered, as predicted from the decay of DTA curve from $1200{ }^{\circ} \mathrm{C}$. These results are compatible with the $\mathrm{SiO}_{2}-\mathrm{Al}_{2} \mathrm{O}_{3}-\mathrm{K}_{2} \mathrm{O}$ phase equilibrium diagram (E.F. Osborn and A. Muan, Phase Diagrams for Ceramists, Plate 5, The American Ceramic Society, 1960)(3), taking into account a) the greater proportion of glassy phase developed in ZS sample in relation to PyH sample, and b) the experimental fact described above that dehydroxilated pyrophyllite is a crystalline phase that persists in a temperature range prior to the simultaneous thermal decomposition to mullite and cristobalite.

Fig. 3 shows the XRD diagrams corresponding to pyrophyllite sample ZS after isothermal treatments of 2 hours. It can be observed the progressive destruction of crystalline lattices of mica (sericite) and pyrophyllite, both dehydroxilated phases, from $1000^{\circ} \mathrm{C}$. The last crystalline phase persists up to $1100{ }^{\circ} \mathrm{C}$ (3,11 A diffraction). Mullite formation is detected at $1000{ }^{\circ} \mathrm{C}$, possibly from thermal decomposition of dehydroxilated mica (sericite) and (meta) kaolinite. Above $1050^{\circ} \mathrm{C}$, the mullite $\mathrm{X}$-ray patterns increase in intensity with temperature treatment. It can be also observed rutile (difraction more intense at 3,23 A) that disappears above $1100{ }^{\circ} \mathrm{C}$. Cristobalite is appreciated after heating at $1200{ }^{\circ} \mathrm{C}$ (Fig.3). Cristobalite persists up to 1350 ${ }^{\circ} \mathrm{C}$ when practically disappeared. In similar raw materials, sericite clays with pyrophyllite and high-sericite pyrophyllite clays, it was not observed the formation of cristobalite even if quartz is present in the samples (3).

Fig. 4 shows, for the sake of comparison, the diagrams of development and evolution of crystalline phase with temperature treatment for pyrophyllite samples $\mathrm{PyH}$ and $\mathrm{ZS}$, where the relative intensities of selected $X$-ray diffractions taken from Figs 2 and 3 are represented as a function of sintering temperature. It is appreciated the progressive destruction of dehydroxilated mica (sericite) and, mainly, dehydroxilated pyrophyllite when temperature increases, besides of the formation of mullite and cristobalite in both pyrophyllite samples. In the case of ZS sample, the formation of mullite and cristobalite occurs at lower temperatures as compared with $\mathrm{PyH}$ sample. Cristobalite may be originated from amorphous silica crystallization, which is segregated by thermal decomposition of (meta)kaolinite and possibly from dehydroxilated pyrophyllite as increasing heating time and/or sintering temperatures. The formation of mullite in ZS sample has a diffe- 
hace que las reacciones se produzcan a temperaturas más bajas respecto a lo que ocurre en las arcillas típicamente caoliníticas utilizadas tradicionalmente en la industria $(3,5)$.

Como se indicó en un trabajo previo de revisión (2), la pirofilita con alto contenido en sericita se viene utilizando desde hace tiempo en pastas cerámicas como sustituto de cuarzo y feldespatos, ya que se obtienen buenas propiedades en el secado y cocción, una mayor resistencia mecánica, aumento del grado de vitrificación, decrecimiento de la temperatura y tiempo de cocción y reducción del cuarteo y la contracción. La propia sericita contribuye a la formación de mullita a baja temperatura, dando lugar a una buena microestructura intergranular y un aumento de la resistencia mecánica, todo lo cual repercute de manera favorable en el consumo energético (18).

Aparte, en la gráfica de la Fig. 4 se observa una evolución progresiva en la disminución de la capacidad de absorción de agua para la muestra de pirofilita ZS desde valores de un $18 \%$ a $900{ }^{\circ} \mathrm{C}$ hasta un $10 \%$ a $1200{ }^{\circ} \mathrm{C}$ al detectarse cristobalita, alcanzando un valor nulo a partir de $1250{ }^{\circ} \mathrm{C}$ y permanece así hasta $1400{ }^{\circ} \mathrm{C}$. Por encima de $1300{ }^{\circ} \mathrm{C}$ el material está constituido por mullita como única fase cristalina y fase vítrea, y la capacidad de absorción de agua, como se observa en la curva, es prácticamente nula. En materias primas similares pero que contienen cuarzo y un contenido relativo mayor de elementos fundentes (6), en las que sólo se observaron indicios de cristobalita únicamente a $1300{ }^{\circ} \mathrm{C}$, no se llega a anular la capacidad de absorción de agua (valores próximos al $2 \%$ ) a $1200^{\circ} \mathrm{C}$, pero permanece constante hasta $1600{ }^{\circ} \mathrm{C}$, obteniéndose resistencias mecánicas de $38 \mathrm{MPa}$ a $1300{ }^{\circ} \mathrm{C}$ y formándose un entramado tupido y característico de cristales alargados de mullita envueltos en fase vítrea. Es interesante destacar la aplicación de las pizarras alumínicas con pirofilita (ZS) como generadores de chamotas mullíticas, con uso potencial en la preparación de productos refractarios medios y gresificados (3-6). La aplicación de la pirofilita ZS objeto del presente trabajo permite la obtención de materiales sinterizados, con buenas resistencias mecánicas y altamente mullíticos por tratamiento térmico a 1200-1300 ${ }^{\circ} \mathrm{C}$ y prácticamente exentas de cristobalita (Fig. 4), lo que favorecería su resistencia al choque térmico.

\subsection{Influencia de tratamientos mecánicos por molienda}

Las materias primas $\mathrm{PyH}$ y ZS se han alterado artificialmente en el laboratorio por modificaciones inducidas mediante tratamientos mecánicos por molienda en seco. Estos tratamientos conducen a una progresiva destrucción de la estructura original de los silicatos presentes. Los diagramas DRX de agregados orientados de estos polvos (Fig. 5), registrados en función del tiempo de molienda, permiten apreciar un aumento de la anchura de los picos y un decrecimiento de las intensidades de los mismos asociados a la disminución del tamaño del microdominio coherente de difracción y al contenido en microtensiones de los cristales, con una total degradación de la estructura cristalina por encima de los 60 minutos. Este proceso es más acusado en los espaciados basales de índices $00 l$ de los silicatos laminares que cambian en mayor extensión que los de índice más general $h k l$, debido a que la alteración por molienda es mayor a lo largo del eje c de la estructura cristalina de los silicatos laminares $(19,20)$.

En las muestras aparecen tres espaciados en la zona $18-21^{\circ} 2 \Theta(4,57 ; 4,44$ y $4,11 \mathrm{~A})$ que corresponden a los planos de índices 002, 110 y 021 de pirofilita, persistiendo sólo el segundo de ellos por encima de 30 minutos y tiende a desaparecer rent origins: from (meta)kaolinite decomposition (DTA exothermic effect at $985^{\circ} \mathrm{C}$ ), and from thermal decomposition of dehydroxilated mica (sericite) and dehydroxilated pyrophyllite. After mullite formation, their patterns shows a constancy with the temperature range here studied, in contrast with cristobalite that disappears above $1300{ }^{\circ} \mathrm{C}$. The formation of mullite by thermal treatment in raw pyrophyllite materials is favourable due to the low particle size of the silicates present in the mixture, their intimate mixture, and the action of fluxing (alkalines in mica or sericite) $(3,5)$. All these factors accelerate the thermal decomposition by firing and produce that the solid-state reactions take place at lower temperatures than in typical kaolinite clays, traditionally applied in the industry.

As it was pointed out in a previous paper (2), high-sericite pyrophyllite has been applied several years ago in ceramic pastes to replace part of quartz and feldspars, because good properties are obtained after drying and sintering, higher mechanical strength, an increase of vitrification degree, a decrease in temperature and time of sintering, and reducing cracking and shrinkage. The content of sericite contributes to the formation of mullite at low temperature, originating a good intergranular microstructure and an increase of mechanical strength, with favourable repercusions in energy consumption (18).

It is also observed in Fig. 4 a progressive diminution of water absoprtion capacity for the pyrophyllite sample ZS from a value of $18 \mathrm{wt} \%$ at $900{ }^{\circ} \mathrm{C}$ to ca. $10 \mathrm{wt} \%$ at $1200{ }^{\circ} \mathrm{C}$ when cristobalite is detected. The water absorption capacity is almost zero at $1250{ }^{\circ} \mathrm{C}$ and above, up to $1400{ }^{\circ} \mathrm{C}$. Above 1300 ${ }^{\circ} \mathrm{C}$, this material is constituted by mullite as a single crystalline phase besides of a glassy phase, and the water absorption capacity is almost zero. In similar raw materials containing quartz and a relative higher content of fluxes (6), the water absorption capacity did not reach almost zero (values ca. 2 wt $\%$ ) at $1200{ }^{\circ} \mathrm{C}$, but it was kept almost constant up to $1600^{\circ} \mathrm{C}$. Mechanical strenght reached a maximum value of $38 \mathrm{MPa}$ at $1300{ }^{\circ} \mathrm{C}$ forming a characteristic microstructure of intergranular elongated-shaped mullite crystals immersed in a glassy phase. In this case, only a very small amount of cristobalite was observed by XRD only at $1300{ }^{\circ} \mathrm{C}$ (6). It is interesting to note the application of this kind of aluminium shales with pyrophyllite (ZS clay) as mullite grogs after firing, with use in the preparation of medium refractories and vitrified (gres) products (3-6). The application of the raw material ZS studied in the present paper allows to obtain sintered materials by firing at $1200-1300{ }^{\circ} \mathrm{C}$, with high-mullite content and good mechanical strength and practically without cristobalite (Fig. 4), which favours the thermal shock resistance.

\subsection{Influence of mechanical treatment by dry grinding}

The raw pyrophyllite materials $\mathrm{PyH}$ and $\mathrm{ZS}$ are altered under laboratory conditions using mechanical treatments by dry grinding. These treatments lead to a progressive destruction of crystalline structures of the silicates. The XRD diagrams in oriented preparation (Fig. 5), recorded as a function of grinding time, allow to observe an increase in X-ray peak broadening and a decrease in their intensities, which is associated to coherent domain diminution and an increase of crystal microstrains. The crystalline structure is completely degraded above 60 minutes. The general $h k l$ reflections of layer silicates change to a lesser extent than the basal 001 reflections because the alteration by dry grinding is greater along the 
posteriormente. Este hecho se atribuye a la propia destrucción del hábito laminar por molienda y, por tanto, a la imposibilidad de realizar verdaderos agregados orientados de las muestras tratadas. En la muestra ZS se comprueba la progresiva degradación de las estructuras cristalinas de la mica (sericita), caolinita y, por último, pirofilita, ya que estos silicatos aparentemente van destruyéndose por tratamiento mecánico. Por encima de 32 minutos, las reflexiones basales de caolinita, pirofilita y mica han desaparecido prácticamente y sólo persiste la (110) de pirofilita que se destruye por encima de 90 minutos. Por tanto, en este momento el ordenamiento a largo alcance ya deja de tener sentido y aumenta el grado de amorfización a los rayos X. En cuanto al ordenamiento a corto alcance, se ha demostrado por espectroscopía MAS NMR que se produce una destrucción parcial de la estructura de pirofilita por molienda y un reordenamiento de los iones $\mathrm{Al}$, inicialmente perfectamente octaédricos, en entornos tetra- y pentaédricos (21). De manera indirecta, puesto que no se detecta fase alguna de carácter cristalino a tiempos altos de molienda, se confirma además la ausencia de cuarzo en la muestra ZS, ya que si existiera en la mezcla persistiría por difracción al ser el cuarzo relativamente mucho más resistente a este tratamiento.

La Figura 6 incluye los datos de superficie específica para las muestras $\mathrm{PyH}$ y ZS en función del tiempo de molienda. El aumento de superficie específica de la pirofilita $\mathrm{PyH}$ se interpreta debido a la disminución del tamaño de las partículas por molienda $(22,23)$, hasta que se llega a un límite de reducción c-axis of the original silicate crystal structures. As a consequence, layer silicate minerals show a pronounced propensity towards cleavage perpendicular to one crystalline axis $(19,20)$.

In these pyrophyllite samples, appear three diffractions in the zone $18-21^{\circ} 2 \Theta(4.57 ; 4.44$ and $4.11 \mathrm{~A})$ which correspond to the reflections 002, 110 and 021, respectively, of pyrophyllite. The second one persits only above 30 minutes, and lastly disappears. The apparition of these three diffractions is attributed to the progressive destruction of the layered shape of the silicates present in the samples by dry grinding, with formation of round aggregates, and thus the difficulties arise to prepare true oriented films from ground powders. In sample $\mathrm{ZS}$, it can be checked the progressive degradation of crystalline structures of mica (sericite), kaolinite and, lastly, pyrophyllite. After 32 minutes, reflections of kaolinite, pyrophyllite and mica have almost disappeared, and the 110 reflection of pyrophyllite remained, but this is destroyed after 90 minutes. Hence, after this time the long-range order is lost and an increase of the amorphization to X-rays is produced. In respect to short-range order, the MAS NMR spectroscopy indicates that the mechanical treatment induced a partial destruction of pyrophyllite crystal structure by progressive dry grinding and a rearrangement of $\mathrm{Al}$ ions, initially octahedral, forming tetraand pentahedral coordinations (21). By an indirect path, it is confirmed that quartz is not present in sample ZS because it

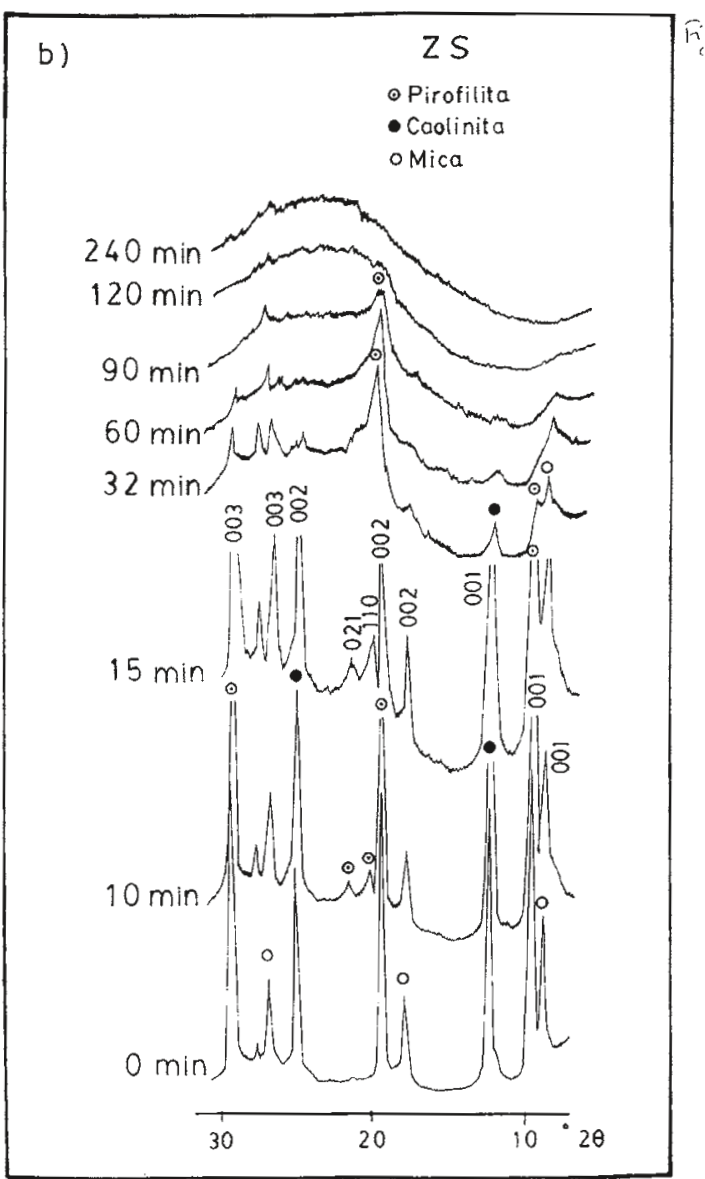

Figura 5.- Difractogramas de rayos X de las muestras de pirofilita (a) PyH y (b) ZS en función del tiempo de molienda (Diagramas de agregados orientados).

Figure 5.- XRD diagrams (thin oriented films) of pyrophyllite samples (a) $\mathrm{PyH}$, and (b) ZS as a function of grinding time. 
mecanoquímica (estimado en 100 A a partir de medidas del tamaño del microdominio cristalino según un plano de índice general 131) a los 30 minutos con un valor máximo de 60 $\mathrm{m}^{2} / \mathrm{g}$. Se estima a este tiempo un máximo valor en el contenido de microtensiones del cristal según el método de la varianza próximo a $4,8 \times 10^{-3}$. Por encima de 30 minutos de molienda, las partículas producidas comienzan a reagregarse y aglomerarse mediante un proceso de "soldadura en frío" debido a la alta reactividad superficial del material, lo que coincide también con un elevado grado de alteración estructural y un aumento de la amorfización (Fig. 5). Este es un comportamiento general en sólidos sometidos a molienda $(24,25)$.

Siguiendo la evolución de superficie específica (S), suponiendo que las partículas de diámetro $\mathrm{D}$ tengan forma esférica y teniendo en cuenta su densidad $\left(\mathrm{d}=2.8 \mathrm{~g} / \mathrm{cm}^{3}\right)$, mediante la fórmula $\mathrm{D}=6 /(\mathrm{dxS})$, se estima una variación desde valores iniciales de unos 3,5 $\mu \mathrm{m}$ hasta $0,1 \mu \mathrm{m}$ a los 7 minutos de molienda, alcanzando valores mínimos de 0,03-0,04 $\mu \mathrm{m}$ entre 15 y 32 minutos, aumentando a partir de aquí debido al proceso de aglomeración. A los 325 minutos se alcanza un valor estimado de $0,30 \mu \mathrm{m}$.

El tratamiento mecánico de la mezcla natural de silicatos (ZS), con densidad media determinada igual a $2,7 \mathrm{~g} / \mathrm{cm}^{3}$, produce un aumento de la superficie específica desde $12 \mathrm{~m}^{2} / \mathrm{g}$ (con tamaño medio de partículas esféricas equivalentes estimado en $0,2 \mu \mathrm{m}$ ) hasta un valor próximo a los $40 \mathrm{~m}^{2} / \mathrm{g}$ a los 32 minutos de molienda, decreciendo el tamaño medio de las partículas presentes en esta mezcla de silicatos hasta un valor mínimo estimado de 0,05 $\mu \mathrm{m}$ y con una formación de partículas aglomeradas debido al proceso de molienda. Se produce entonces una disminución progresiva de los valores de superficie específica hasta valores en torno a $8,4 \mathrm{~m}^{2} / \mathrm{g}$ a los 240 minutos y un valor medio estimado del tamaño de las partículas de $0,26 \mu \mathrm{m}$. Estos cambios se pueden seguir, asimismo, por $\operatorname{MEB}(22,26,27)$. Por molienda se forman aglomerados irregulares y progresivamente más densos, comprobándose la destrucción del carácter laminar inicial. Estos aglomerados están constituidos por pequeñas partículas agregadas muy íntimamente entre sí.

Sin embargo, teniendo en cuenta resultados obtenidos en la molienda de caolinita (27) empleando las mismas condiciones experimentales que para estas materias primas con pirofilita, cuya evolución de superficie específica se incluye en la Fig. 6, ha de atribuirse que el comportamiento observado para la muestra ZS se debe principalmente a la presencia de pirofilita, a pesar de su valor inicial más elevado de superficie específica respecto a la pirofilita pura $(\mathrm{PyH})$. En un trabajo (28) sobre molienda de una mezcla con una composición mineralógica aproximada de $54 \%$ de pirofilita, $22 \%$ de caolinita y $16 \%$ de mica y cantidades inferiores al $3 \%$ de otros minerales, se ha encontrado que la evolución de superficie específica con el tiempo de molienda presenta dos máximos. El primero de ellos, a $50 \mathrm{~m}^{2} / \mathrm{g}$ atribuido a pirofilita que, según estos autores (28), es más alterable que caolinita, lo que está en desacuerdo con los resultados aquí expuestos y en contra de lo inicialmente supuesto teniendo en cuenta sus respectivas estructuras cristalinas, esto es, más alterable la caolinita al ser un silicato 1:1 frente a la pirofilita, que lo es 2:1. El otro máximo, a 70 $\mathrm{m}^{2} / \mathrm{g}$ (28) se atribuye a caolinita, aunque los resultados de difracción de rayos $\mathrm{X}$ indicaron, asimismo, que este silicato ha desaparecido prácticamente a las 16 horas de molienda, a diferencia de algunas difracciones de pirofilita que persisten, como demuestran también los resultados aquí presentados e incluidos en la Fig. 5. Esto ocurre, sobre todo, en cuanto a la persistencia de la difracción de índice 110. shows more relative resistance to the mechanical treatment and this phase is not detected at long grinding times.

Fig. 6 shows the surface area results of samples $\mathrm{PyH}$ and ZS plotted as a function of grinding time. The increase of surface area of $\mathrm{PyH}$ sample is interpreted due to a diminution of particle size as a consequence of grinding treatment $(22,23)$. This is produced up to reach a limit of mechanochemical reduction estimated in a size of ca. $100 \mathrm{~A}$ from coherent domain measurements of the 131 reflection after 30 minutes, with a maximum value of surface area of $60 \mathrm{~m}^{2} / \mathrm{g}$, and a maximum value of microstrains (variance method) of ca. $4,8 \times 10^{-3}$. Above 30 minutes of grinding time, the particles start to reaggregate and agglomerate by a "cold-welding" process due to the high and enhanced surface reactivity of the ground powders, which coincides with the strong structural alteration and amorphization as deduced by XRD (Fig. 5). This is a general behaviour of solids submitted to grinding and considered changes inside of the mechanochemical reactions $(24,25)$.

Following the evolution of surface area (S) and assuming that the particles of diameter $\mathrm{D}$ have spherical shape and uniform density $\left(\mathrm{d}=2.8 \mathrm{~g} / \mathrm{cm}^{3}\right)$, using the equation $\mathrm{D}=6 /(\mathrm{dxS})$, it is estimated a variation of average starting values ( 0 minutes) of $3.5 \mu \mathrm{m}$ to $0.1 \mu \mathrm{m}$ after 7 minutes of grinding time, reaching minimum values of $0.03-0.04 \mu \mathrm{m}$ between 15 and 32 minutes. After this, the particle size apparently increases due to the agglomeration process. After 325 minutes, the estimated value is $0.30 \mu \mathrm{m}$.

The mechanical treatment by dry grinding of the sample ZS produce an increase of surface area values from $12 \mathrm{~m}^{2} / \mathrm{g}$ (and with average density of $2.7 \mathrm{~g} / \mathrm{cm}^{3}$, an equivalent spherical particle size of ca. $0.2 \mu \mathrm{m}$ ) to ca. $40 \mathrm{~m}^{2} / \mathrm{g}$ after 32 minutes of

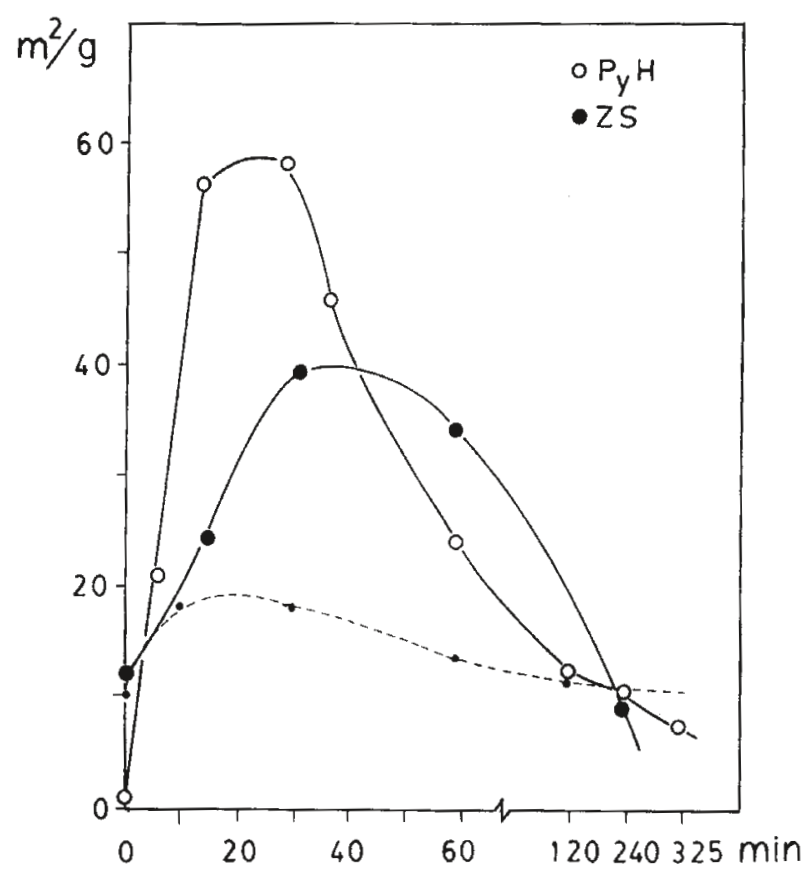

Figura 6.- Evolución de la superficie específica $\left(\mathrm{m}^{2} / \mathrm{g}\right)$ en función del tiempo de molienda para las muestras de pirofilita PyH y ZS. Se incluyen a efectos comparativos los resultados para caolinita (línea punteada) (27).

Figure 6.- Evolution of surface areas $\left(\mathrm{m}^{2} / \mathrm{g}\right)$ plotted as a function of grinding times for pyrophyllite samples $\mathrm{PyH}$ and $\mathrm{ZS}$. The results for a standard kaolinite sample are included (dashed line) (27). 
Asimismo, el estudio textural realizado en estas materias primas sometidas a tratamiento mecánico por molienda en seco (29) ha permitido comprobar la ausencia de microporos, obteniéndose isotermas de adsorción-desorción de gas nitrógeno a $77 \mathrm{~K}$ propias de agregados o partículas de hábito laminar con poros en forma de rendija, decreciendo la superficie específica por encima de 30 minutos de molienda, como indica la Fig. 6.

\subsection{Influencia de tratamientos mecánicos y térmicos}

La influencia de tratamientos mecánicos y térmicos en materias primas con pirofilita se ha estudiado mediante análisis térmico (ATD y TG). En la muestra $\mathrm{PyH}$, la molienda produce cambios importantes en las curvas de ATD-TG (Fig. 7a), produciéndose pérdidas de peso a más baja temperatura que en la materia prima no tratada. El efecto de deshidroxilación se desplaza desde unos $780{ }^{\circ} \mathrm{C}$ en el material no tratado hasta $540{ }^{\circ} \mathrm{C}$ (temperatura del efecto) a los 30 minutos debido a la disminución del tamaño de las partículas y al aumento de superficie específica. Como aspecto importante a destacar es el desarrollo de un efecto exotérmico apreciable a $1000{ }^{\circ} \mathrm{C}$ que no es propio de pirofilita (Figura 7a). Considerando la baja proporción presente de caolinita, este efecto exotérmico, que aumenta en intensidad al aumentar el tiempo de molienda, se asocia a la formación de mullita mediante tratamientos mecánicos y térmicos combinados (Fig. 8a). grinding, showing a minimum value of particle size reduction of $0.05 \mu \mathrm{m}$. After this, a progressive decrease in surface areas is observed with formation of agglomerated particles by the progressive grinding up to values of $8,4 \mathrm{~m}^{2} / \mathrm{g}$ after $240 \mathrm{minu}$ tes with equivalent spherical particle size of $0.26 \mu \mathrm{m}$. These mechanochemical changes can be followed by electron microscopy $(22,26,27)$. The irregular agglomerates, progressively denser, are formed by dry grinding of $\mathrm{PyH}$ and $\mathrm{ZS}$ pryophyllite samples, with destruction of the layered shape initially present. These agglomerates are constituted by very small particles aggregated between them and intimate mixed.

The surface area evolution by dry grinding of standard kaolinite is included in Fig. 6 (27). Taking into account these results and those of $\mathrm{PyH}$ sample, the evolution of surface area observed for sample ZS can be associated mainly to the presence of pyrophyllite in this raw material in despite of the higher surface area value compared with pure pyrophyllite $(\mathrm{PyH})$. In relation with this, in a natural mixture of $54 \%$ pyrophylllite, $22 \%$ kaolinite, $16 \%$ mica and minor amounts $(<3 \%)$ of other minerals, it has been reported a surface area evolution with two peak maxima (28). The first one at $50 \mathrm{~m}^{2} / \mathrm{g}$ was attributed to pyrophyllite, which shows easy alteration than kaolinite as claimed by these authors (28). This is in disagreement with the present results concerning pyrophyllite samples $\mathrm{PyH}$ and ZS, and it is not consistent according to the respective crystalline structures of kaolinite (1:1 layer silicate) and pyrophyllite (2:1 layer silicate). Pyrophyllite, with two tetrahedral silica layers would be more difficult to alterate by grinding as compared with kaolinite (1:1) under the same experimental consitions. The second relative maximum at $70 \mathrm{~m}^{2} / \mathrm{g}$ was attributed to kaolinite

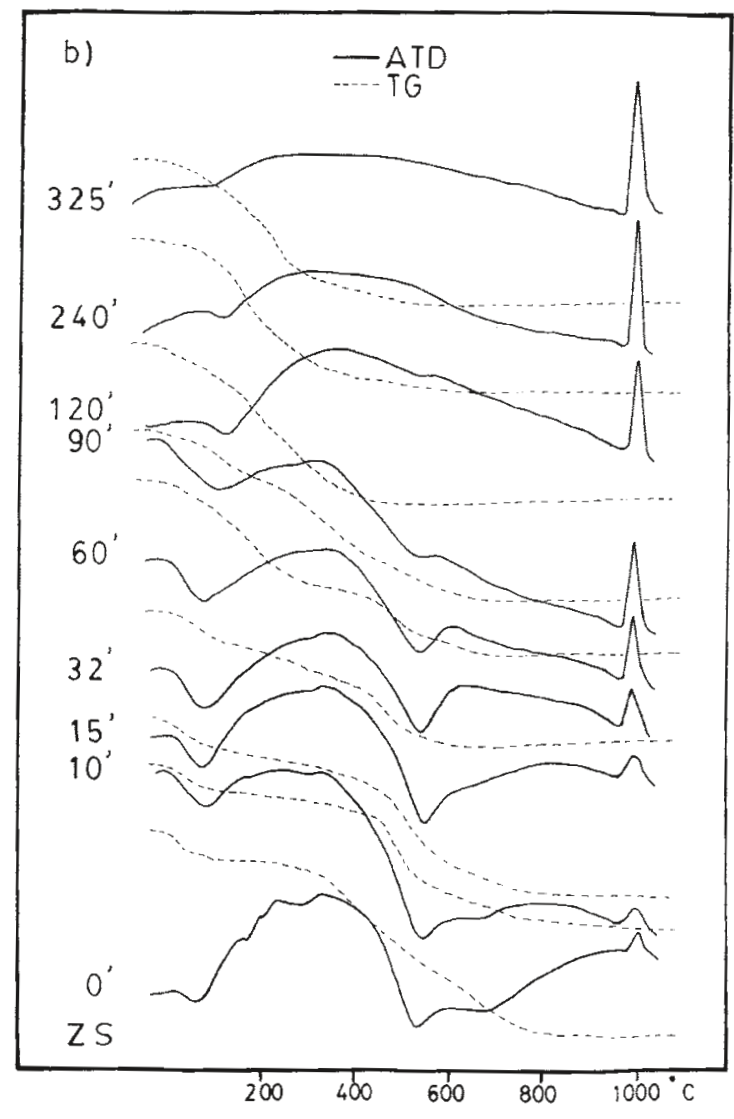

Figura 7.- Curvas de análisis térmico (ATD-TG) para las muestras (a) PyH y (b) ZS en función del tiempo de molienda.

Figure 7.- Thermal analysis curves (DTA-TG) of pyrophyllite samples (a) $\mathrm{PyH}$, and (b) ZS as a function of grinding time. 
Como indica la Fig. 8a (comparación a $1050{ }^{\circ} \mathrm{C}$ ), se destruye progresivamente la red cristalina de pirofilita y de su correspondiente fase deshidroxilada, nucleándose simultáneamente la mullita. No obstante, nunca se llega a producir la fase deshidroxilada por molienda, sino por el tratamiento térmico posterior y a más baja temperatura $\left(540{ }^{\circ} \mathrm{C}\right.$, Fig. $\left.7 \mathrm{a}\right)$. En este sentido, la disminución progresiva del tamaño de las partículas por molienda produce que la deshidroxilación tenga lugar a temperaturas inferiores si se compara con la muestra original, pero hasta llegar a un límite, o límite de reducción mecanoquímica de las partículas, coincidente con el máximo valor de área superficial específica (Fig. 6).

En la mezcla natural de silicatos con pirofilita (ZS) se produce un proceso similar (Fig. $7 \mathrm{~b}$ ), si bien los efectos endotérmicos de caolinita $\left(560^{\circ} \mathrm{C}\right)$ y pirofilita $\left(680^{\circ} \mathrm{C}\right)$ se detectan a temperaturas del orden de $510{ }^{\circ} \mathrm{C}$ a los 60 minutos, llegan a solapar y desaparecen por encima de 90 minutos de molienda. Sin embargo, al desaparecer la caolinita por encima de 60 minutos de molienda (Fig. 5), el efecto endotérmico por encima de 500 ${ }^{\circ} \mathrm{C}$ ha de atribuirse a la pirofilita remanente. Se puede demostrar que el aumento de intensidad del exotérmico está asociado únicamente a la presencia de pirofilita y resulta ser independiente del contenido en caolinita y de mica (ilita), al menos hasta 325 minutos de molienda bajo las mismas condiciones experimentales $(26,29)$. La curva de ATD de una mica (ilita de tamaño de partícula inferior a $2 \mu \mathrm{m}$ ), no experimenta cambios notables si la muestra inicialmente se ha molido y tampoco se ha observado la formación de efecto exotérmico alguno de
(28), although their XRD results indicated that the patterns of this silicate have disapperared practically after 16 hours of grinding, in contrast with that occurs with pyrophyllite according to the results of these authors (28), and those of the present paper included in Fig. 5. This occurs, mainly, taking into account the persistence of 110 reflection.

Finally, the textural study of these raw materials after dry grinding (29) has allowed to check the absence of micropores after the determination and study of adsorption-desorption isotherms of nitrogen gas at liquid nitrogen temperature $(77 \mathrm{~K})$. The shape of these isotherms are associated to aggregates or particles with layer shape and slit-shaped pores, decreasing the surface area above 30 minutes of grinding, as shown Fig. 6 .

\subsection{Influence of mechanical and thermal treatments}

The study of the influence of combined mechanical and thermal treatments on pyrophyllite raw materials was performed by thermal analysis (DTA-TG). Grinding of $\mathrm{PyH}$ sample produces important changes in the shape of DTA-TG diagrams (Fig. 7a), with weight loss (water) at lower temperatures than in unground samples as increasing grinding time. The structural dehydroxilation takes place from $780{ }^{\circ} \mathrm{C}$ to $540{ }^{\circ} \mathrm{C}$ after 30 minutes. The diminution of particle size of the layer silicate by grinding and the increase of surface areas contribute to that behaviour. An importan aspect is the formation and development of an exothermic DTA effect at $1000{ }^{\circ} \mathrm{C}$ that is not characteristic of pyrophyllite (Figura 7a), only of kaolinite. This effect increases in
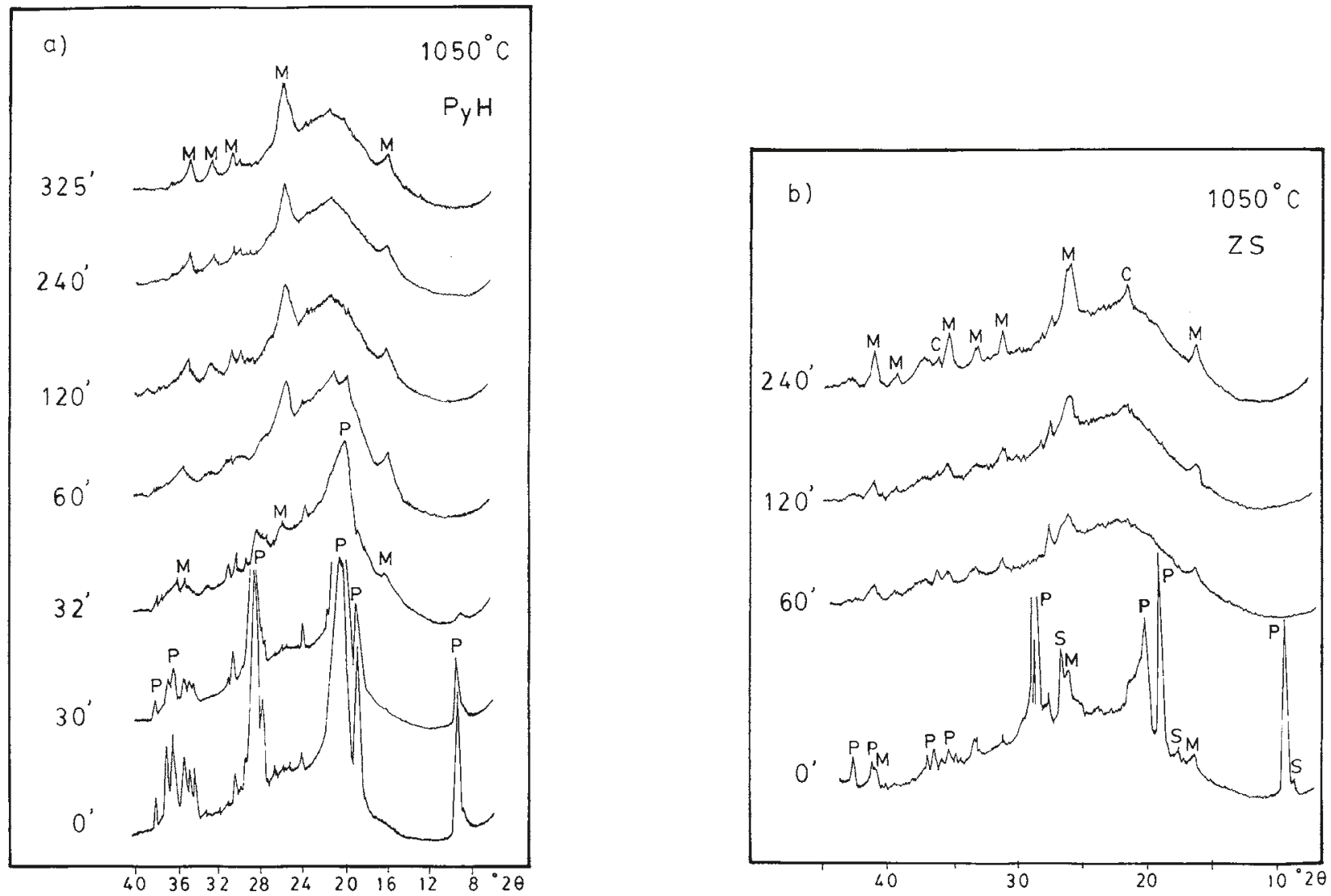

Figura 8.- Difractogramas de rayos $\mathrm{X}$ de las muestras (a) $\mathrm{PyH}$ y (b) $\mathrm{ZS}$ tratadas a $1050{ }^{\circ} \mathrm{C}$ en función del tiempo de molienda.

Figure 8.- XRD diagrams of original and ground pyrophyllite samples (a) PyH and (b) ZS after heating at $1050{ }^{\circ} \mathrm{C} . \mathrm{P}=$ Dehydroxilated Pyrophyllite; $\mathrm{M}=$ Mullite; $\mathrm{C}=$ Cristobalite; $\mathrm{S}=$ Dehydroxilated Mica (Sericite). 
importancia, a diferencia de lo que ocurre en caolinita y pirofilita, esta última sometida a una molienda previa (29).

En el caso de la caolinita, aunque existen resultados previos contradictorios sobre su evolución térmica en muestras previamente molidas (28,30-33), se ha demostrado en un trabajo muy reciente que el efecto exotérmico de ATD permanece inalterado por una molienda previa de la caolinita (27). Para ello se empleó una muestra de caolinita estándard suministrada por The Clay Minerals Society, a diferencia de las muestras de caolinita empleadas por otros autores (30-33). Teniendo en cuenta los resultados precedentes sobre molienda de pirofilita pura, este efecto exotérmico en la curva de ATD se produce, asimismo, en la misma mezcla molida debido a la formación de mullita a partir de pirofilita, lo que ocurre a temperatura más baja por tratamiento mecánico de la misma combinado con otro térmico. Esta mullita se une a la propia mullita formada a partir de la caolinita presente en la mezcla original (Fig.8b), lo que se comprueba al comparar los difractogramas para la mezcla ZS de la Fig. 8b y los mostrados en la Fig. 2. En relación a lo anterior, teniendo en cuenta resultados previos obtenidos por espectroscopía MAS-NMR (21), se considera que la molienda produce la destrucción parcial de la estructura de pirofilita y un reordenamiento de los iones $\mathrm{Al}$ en entornos tetra- y pentaédricos, inicialmente octaédricos y con grupos $\mathrm{OH}$ enlazados directamente a estos iones.

La molienda progresiva produce, además, la rotura de la capa tetraédrica de grupos $\mathrm{SiO}_{4}$ que favorece la difusión atómica de $\mathrm{Al}$ y, en consecuencia, la formación de núcleos de mullita, ricos en $\mathrm{Al}$ y pobres en $\mathrm{Si}$, a la temperatura de $1000{ }^{\circ} \mathrm{C}$ en calentamiento dinámico, esto es, el efecto exotérmico intenso detectado en las curvas de ATD (Fig. 8). Este proceso ocurre súbitamente con la activación térmica, en contraste con lo que sucede en el silicato sólo tratado térmicamente (Figs. 1 y 2) bajo las mismas condiciones, en el cual la mullita se forma a unos $1200{ }^{\circ} \mathrm{C}$. La detección de un efecto exotérmico intenso y agudo en las curvas de ATD de las muestras de pirofilita molida se ascribe a la transformación de la coordinación pentaédrica del $\mathrm{Al}$, presente en el material molido, a coordinaciones más estables tetra- y octaédrica de $\mathrm{Al}$ presentes en la mullita. Desde otra perspectiva, la formación de un efecto exotérmico intenso en las curvas de ATD (Fig. 7) de pirofilita molida está asociada a un cambio en la coordinación de los iones $\mathrm{Al}$ con una liberación de energía, como sucede análogamente en la caolinita pero sólo tratada térmicamente (12).

Asimismo, es de destacar que durante la reacción de descomposición térmica de pirofilita molida, se produce una segregación de sílice amorfa, comparándose los resultados obtenidos en este proceso, por su gran similitud, con los de la transformación caolinita-mullita estudiada previamente en la bibliografía $(12,34,35)$. Se detecta en la curva de ATD un débil efecto endotérmico a $950{ }^{\circ} \mathrm{C}$ que precede al intenso exotérmico (Fig. 8) asociado a este tipo de segregación que se da en caolinita sólo tratada térmicamente $(9,12)$. En los difractogramas de la Fig. 8 para la mezcla ZS se puede observar la formación de cristobalita a partir de la cristalización de la sílice amorfa segregada a la temperatura de $1050{ }^{\circ} \mathrm{C}$, a diferencia de lo que ocurre en la muestra sólo tratada térmicamente (Fig. 4).

Por otra parte, en principio no sería descartable la formación de una fase tipo espinela Si-Al, fase cúbica, ó $\gamma$-alúmina, como sucede en la transformación térmica de caolinita a mullita, según algunos autores y que ha sido causa de una larga controversia en la bibliografía $(12,36)$. La formación de un efecto exotérmico en la curva de ATD de caolinita ha sido atribuida a mullita o espinela o incluso ambas fases, dado que a las velo- intensity (peak areas) as increasing grinding time and is associated to mullite formation by combined mechanical and thermal treatments, according to the XRD study (Fig. 8a).

As shown Fig. 8a (comparison of $1050^{\circ} \mathrm{C}$ ), the crystal structure of pyrophyllite and that of the corresponding dehydroxilated phase are destroyed progressively by combined mechanical and thermal treatments. At the same time, mullite nucleation takes place. However, dehydroxilated pyrophyllite is not produced by dry grinding, only by thermal treatment but at lower temperatures $\left(540^{\circ} \mathrm{C}\right)$. In this sense, the progressive diminution of particle size by dry grinding produces the dehydroxilation at lower temperatures as compared with the original (unground) samples. The decrease in particle size causes the elimination of structural $\mathrm{OH}$ groups of remaining pyrophyllite at lower temperatures in ground than in unground samples, where a more defective or stressed structure is also being produced by mechanical treatment. This is produced up to a reduction limit, or limit of mechanochemical reduction when surface area reached a maximum value (Fig. 6).

Concerning the natural mixture of silicates with pyrophyllite (ZS), a similar process as described above is produced (Fig. 7b), although the endothermic DTA effects corresponding to pyrophyllite $\left(680^{\circ} \mathrm{C}\right)$ and kaolinite dehydroxilation $\left(540{ }^{\circ} \mathrm{C}\right)$ are observed at ca. $510{ }^{\circ} \mathrm{C}$ (60 minutes). Both effects overlapped and disappeared above 90 minutes of grinding time. However, because kaolinite $\mathrm{X}$-ray reflections disappeared above $60 \mathrm{minu}$ tes (Fig. 5), the endothermic DTA effect above $500{ }^{\circ} \mathrm{C}$ must be attributed to remaining pyrophyllite. It can be demonstrated that the increase in intensity of the exothermic is only associated to the presence of pyrophyllite in the mixture, irrespective of the other aluminium silicates present in the samples, at least up to 325 minutes of dry grinding under the same experimental conditions $(26,29)$. The DTA diagram of a mica sample (purified illite of particle size lower than $2 \mu \mathrm{m}$ ), did not show any changes if the sample is previously ground, with no formation of such exothermic DTA effect at $1000^{\circ} \mathrm{C}$, in contrast to that occurs in kaolinite and ground pyrophyllite (29).

For kaolinite, contradictory results on the evolution of the exothermic DTA effect after grinding have been reported in the literature (28,30-33). In a recent paper, it has been demonstrated that no increases in exothermic DTA intensity (peak areas) was recorded after dry grinding of kaolinite powders, at least up to 325 minutes (27). For that purpose, a standard kaolinite sample supplied by The Clay Mineral Society was used, in contrast with different and non-standards kaolinite samples studied by other authors (30-33). Taking into account the precedent results on pure pyrophyllite sample $(\mathrm{PyH})$ by dry grinding, this exothermic DTA effect is produced in the natural mixture (ZS) due to the formation of mullite from pyrophyllite by combined mechanical and thermal treatments at lower temperatures than in unground samples. This mullite formation is added to that mullite coming from (meta)kaolinite thermal decomposition present in the sample (Fig.8b), which is deduced by comparison of XRD diagrams of sample ZS (Fig. $8 \mathrm{~b}$ ) and those of Fig. 2. In relation with this, taking into account previous results obtained by MAS-NMR spectroscopy (21), it is considered that dry grinding produces the destruction of the crystal structure of pyrophyllite and a rearrangement of $\mathrm{Al}$ ions, initialy in octahedral coordination, in tetra- and pentahedral coordinations, with $\mathrm{OH}$ groups directly bonded to these $\mathrm{Al}$ ions.

The progressive dry grinding also produces the tetrahedral structural breakdown of $\mathrm{SiO}_{4}$ groups which favours the atomic diffusion of $\mathrm{Al}$ ions and, hence, the formation of Al-rich mulli- 
cidades de calentamiento empleadas en ATD estas dos fases tienen la posibilidad de formarse de manera concurrente (9). En este sentido, es de destacar que el límite de composición inferior para la formación de una espinela $\mathrm{Si}-\mathrm{Al}$ es del $30 \%$ de $\mathrm{Al}_{2} \mathrm{O}_{3}$ según Okada y Otsuka (37), valor que es, a su vez, la cantidad máxima presente en pirofilita (Tabla 1) pero no así en caolinita que es de un $45 \%$ en peso. De acuerdo con este dato de la bibliografía, nunca se formará una espinela de este tipo a partir de pirofilita tratada térmicamente, ni tampoco mediante un tratamiento previo a éste de molienda, a tenor de los resultados obtenidos y a diferencia de lo que ocurre en la caolinita $(9,12,35)$. No obstante, en el caso de la muestra ZS no se descarta la formación de la fase tipo espinela debido a la presencia de caolinita junto a pirofilita en la mezcla.

Finalmente, si se tienen en cuenta los datos expuestos sobre descomposición térmica de pirofilita (apartado 3.1), se puede deducir que la formación de mullita a partir del silicato laminar de tipo 2:1 requiere un reordenamiento de los iones $\mathrm{Al}$, lo que está impedido a priori por la existencia de dos capas de tetraedros $\mathrm{SiO}_{4}$ que rodean a los octaedros con grupos $\mathrm{AlO}_{4}(\mathrm{OH})_{2}$ y que impiden la difusión atómica de $\mathrm{Al}$ en pirofilita para originar mullita (21). Esta estructura es, además, más resistente al tratamiento de molienda que la caolinita (27), donde sólo existe una capa de tetraedros $\mathrm{SiO}_{4}$. La destrucción de la capa tetraédrica en la pirofilita mediante molienda elimina, por tanto, esta restricción y disminuye la temperatura de formación de los núcleos de mullita desde 1200 a $1000{ }^{\circ} \mathrm{C}$ en calentamiento dinámico (ATD). La destrucción de dicha capa tetraédrica favorece también, a su vez, la incorporación de Si en los núcleos de mullita ricos en $\mathrm{Al}$ durante un tratamiento térmico que se realice posteriormente por encima de $1000^{\circ} \mathrm{C}$.

Es de interés mencionar que mediante espectroscopía de fotoelectrones se ha observado un enriquecimiento en aluminio al formarse mullita, lo que está originado por una segregación superficial de una fase de mayor contenido en aluminio (29). Los agregados enriquecidos en aluminio son de mayor tamaño si se somete el silicato previamente a un tratamiento mecánico por molienda. Dicho tratamiento produce, además, una disminución de la energía de enlace de los niveles $\mathrm{Al}(2 \mathrm{p})$, lo que justifica la pérdida de los grupos $\mathrm{OH}$ a más baja temperatura al ser sometido el material previamente molido a un tratamiento térmico.

\section{SUMARIO Y CONCLUSIONES}

En el presente trabajo se exponen y discuten resultados obtenidos en investigaciones llevadas a cabo sobre la influencia de tratamientos térmicos, mecánicos por molienda en seco y su combinación en materias primas con pirofilita. Se han estudiado dos muestras con pirofilita (Tabla 1): (a) muestra PyH, con $90 \%$ de pirofilita y (b) muestra ZS, una pizarra alumínica con $40 \%$ de pirofilita, $30 \%$ de caolinita y $30 \%$ de mica (sericita). Sobre la base de resultados previos en relación a tratamientos térmicos de la muestra $\mathrm{PyH}$, se han analizado las transformaciones térmicas que ocurren en la mezcla natural de silicatos con pirofilita (muestra ZS). El análisis térmico por ATD-TG confirmó la presencia de una pirofilita normal que constituye la muestra $\mathrm{PyH}$ y el solapamiento de los efectos térmicos de los silicatos presentes en la muestra ZS, en particular la detección de un efecto exotérmico a $985^{\circ} \mathrm{C}$ asociado a la descomposición térmica de metacaolinita y no a pirofilita.

A partir de resultados obtenidos por DRX, se deduce que el tratamiento térmico de pirofilita produce la formación de te nuclei at $1000{ }^{\circ} \mathrm{C}$ by dynamic heating, i.e., the detection of an exothermic effect in the DTA curve (Fig. 7). This process occurs suddenly with thermal activation, in contrast with that occurs in pyrophyllite submitted only to thermal treatments (Figs. 1 and 2) under the same conditions in which mullite is produced at ca. $1200{ }^{\circ} \mathrm{C}$. The previous NMR study (21) made possible the assignment of the exothermic DTA peak detected at $1000{ }^{\circ} \mathrm{C}$ to the transformation of the coordination of $\mathrm{Al}$ from the unstable pentahedral and/or tetrahedral form of the ground pyrophyllite to the more favourable octahedral coordination in the mullite nuclei. From an energetic point of view, the formation of an intense DTA exothermic peak in ground and heated pyrophyllite samples (Fig. 7) is associated to a change in $\mathrm{Al}$ coordination with a release of energy, as occurs after heating unground kaolinite (12).

Heating of ground pyrophyllite between $950-1050{ }^{\circ} \mathrm{C}$ produces the formation of Al-rich mullite precursors and segregation of amorphous silica. A small endothermic effect is detected in the DTA curves of pyrophyllite at $950{ }^{\circ} \mathrm{C}$ inmediately before the sharp exothermic (Fig. 7) that is associated to silica segregation, as pointed out in the study of heating kaolinite and called the faint endotherm $(9,12)$. This effect has been reported in the thermal transformation of (meta)kaolinite to mullite and produced inmediately before the sharp exothermic effect, as described in the literature $(12,34,35)$. Examining the XRD diagrams of Fig. 8 for ground and heated pyrophyllite sample $\mathrm{ZS}$, it can be observed the formation of cristobalite from the crystallization of amorphous silica previously segregated at ca. 950-1050 ${ }^{\circ} \mathrm{C}$, in contrast with that occurs in the same unground sample but only after thermal treatments (Fig. 4).

On the other hand, it would be not rejected the formation of a Si-Al spinel, cubic phase, or $\gamma$-alumina, as occurs in the thermal transformation of (meta)kaolinite to mullite according to several authors. This is the main cause of the DTA exothermic effect and has been controversial in the literature $(9,12,36)$. It has been attributed to the formation of either mullite nuclei or a transient alumina-type Al-Si spinel $\left(\gamma-\mathrm{Al}_{2} \mathrm{O}_{3}\right.$ solid solution) or both, because at DTA heating rates both mullite and spinel have the possibilite of forming concurrently (9). In this sense, it must be noted that the lower limit of composition for the formation of Al-Si spinel is $30 \mathrm{wt} \% \mathrm{Al}_{2} \mathrm{O}_{3}$ according to Okada and Otsuka (37). This value is the maximum amount of $\mathrm{Al}_{2} \mathrm{O}_{3}$ that is present in pyrophyllite (Table 1) but is not in kaolinite $(45 \mathrm{wt} \%)$. Thus, the formation of spinel phase is not possible in pyrophyllite after thermal treatment, and neither by combined mechanical by dry grinding and thermal treatments according to the present results and those obtained in kaolinite $(9,12,35)$. However, the spinel phase could be formed in the case of sample ZS because of kaolinite is present.

Finally, if they are considered the results of thermal decomposition of pyrophyllite (section 3.1), it can be deduced that the formation of mullite from pyrophyllite (layer silicate) requires previous $\mathrm{Al}$ rearrangement, which is hindered a priori by the existence of the two tetrahedral sheets of $\mathrm{SiO} 4$ groups that surrounds the octahedral one of $\mathrm{AlO} 4(\mathrm{OH}) 2$ groups and impedes $\mathrm{Al}$ atomic diffusion in pyrophyllite to form mullite (21). This structural feature makes more resistent pyrophyllite to structural alteration by dry grinding as compared with kaolinite (27), where there is only one tetrahedral sheet of $\mathrm{SiO} 4$ groups. Destruction of the tetrahedral layer by dry grinding eliminates that restriction, decreasing the temperature of mullite nuclei formation from 1200 to $1000{ }^{\circ} \mathrm{C}$ in ground samples after heating under dynamic conditions (DTA). Tetrahedral sheet destruction favours also the incorporation of $\mathrm{Si}$ in Al-rich mullite nuclei during thermal treatment of samples above $1000^{\circ} \mathrm{C}$. 
la estructura cristalina de pirofilita deshidroxilada. Dicha fase cristalina persiste hasta los $1200{ }^{\circ} \mathrm{C}$ cuando se forma mullita por cristalización, lo que sucede a $1215^{\circ} \mathrm{C}$. La cristobalita cristaliza a $1325^{\circ} \mathrm{C}$ a partir de la sílice amorfa producida en la descomposición térmica previa de la pirofilita deshidroxilada. Se concluye que el tratamiento térmico prolongado favorece la formación de nuesvas fases cristalinas a temperaturas más bajas, lo que indica la existencia de importantes efectos cinéticos en la descomposición térmica de pirofilita. En la muestra ZS, la nucleación de mullita se produce al detectarse el efecto exotérmico de ATD a $985^{\circ} \mathrm{C}$. Al aumentar la temperatura, desaparece progresivamente la pirofilita deshidroxilada y no se detecta ya a $1200{ }^{\circ} \mathrm{C}$, registrándose a partir de esta temperatura un aumento en intensidad de las difracciones de mullita. La mullita se produce en la muestra ZS a partir de la descomposición térmica de las redes de mica (sericita) y pirofilita deshidroxiladas, así como a partir de la metacaolinita. La formación de mullita y cristobalita en la esta muestra se produce a una temperatura relativa más baja que en la muestra PyH. Después de la formación de mullita, la intensidad de sus difracciones presentan una constancia con la temperatura de tratamiento, en contraste con la fase cristobalita que desaparece por encima de $1300{ }^{\circ} \mathrm{C}$. Esta fase se aprecia por DRX en la muestra ZS después de tratamiento térmico a $1200{ }^{\circ} \mathrm{C}$, o bien aumentando el tiempo de tratamiento y se nuclea previamente por tratamiento térmico a partir de sílice amorfa. Se obtienen materiales sinterizados mediante tratamiento térmico a $1200-1300{ }^{\circ} \mathrm{C}$ que presentan un alto contenido relativo de mullita, buenas resistencias mecánicas en frío y prácticamente exentos de cristobalita.

Las materias primas con pirofilita se han alterado mediante tratamiento mecánico por molienda en seco en condiciones de laboratorio. Este tratamiento produce efectos notables sobre la estructura y propiedades de los sólidos o cambios mecanoquímicos debidos a un aumento de reactividad de los sistemas por molienda (activación mecánica). En general, la molienda conduce a una progresiva destrucción de la estructura cristalina original de los silicatos laminares presentes, pero esto sucede preferencialmente siguiendo una dirección a lo largo del eje " $\mathrm{c}$ ", es decir, la rotura se produce perpendicular a un eje cristalino del retículo. En consecuencia, las reflexiones basales $00 l$ se alteran más rápidamente que las de índice más general. La estructura de la pirofilita se degrada completamente por encima de 60 minutos de molienda. La reflexión 110 persiste por encima de los 30 minutos y finalmente desaparece con destrucción del hábito laminar de los silicatos presentes en la muestra, aumento de la amorfización y formación de agregados irregulares redondeados progresivamente más densos. En la muestra ZS, se registra la degradación de la estructura cristalina de mica (sericita), caolinita y, finalmente, pirofilita en esta secuencia. Considerando la estructura cristalina de caolinita (silicato laminar 1:1) y pirofilita (silicato laminar 2:1), se concluye que la pirofilita, con dos capas de tetrahedros (grupos $\mathrm{SiO}_{4}$ ) es más difícil de alterar por tratamiento mecánico de molienda en seco si se compara con la caolinita (1:1) bajo las mismas condicones experimentales.

El aumento de superficie específica de la muestra $\mathrm{PyH}$ al aumentar el tiempo de molienda se ha interpretado debido a la disminución del tamaño de las partículas como consecuencia del tratamiento hasta llegar a un límite o límite de redución mecanoquímica (ca. 100 A después de 30 minutos), con un valor máximo de superficie específica de $60 \mathrm{~m}^{2} / \mathrm{g}$ en
It is interesting to mention that using X-ray photon spectroscopy (XPS) was observed a surface enrichment of Al during mullite formation by heating of pyrophyllite samples, which is originated by a surface segregation of a phase of higher Al-content (29). The aggregates enriched in $\mathrm{Al}$ are of greater size if pyrophyllite is previously submitted to a mechanical treatment by dry grinding. This treatment also produces a decrease of energy bond of $\mathrm{Al}(2 \mathrm{p})$ levels, which may justify the loss of $\mathrm{OH}$ groups coordinated to the $\mathrm{Al}$ ions at lower temperatures during thermal treatment of ground samples of raw materials containing pyrophyllite (Fig. 8).

\section{SUMMMARY AND CONCLUSIONS}

In this work, results obtained in a research study on the influence of thermal, mechanical by dry grinding, and their combination, in raw materials containing pyrophyllite, have been discussed. Two samples of raw materials containing pyrophyllite (Table 1) were selected: (a) $\mathrm{PyH}$ sample, with 90 wt\% pyrophyllite, and (b) ZS sample, an aluminium shale with $40 \mathrm{wt} \%$ pyrophyllite, $30 \mathrm{wt} \%$ kaolinite, and $30 \mathrm{wt} \%$ mica (sericite). On the basis of previous results on thermal treatments of pyrophyllite $\mathrm{PyH}$, it was analyzed the thermal transformations in the natural raw mixture with kaolinite and mica (ZS sample). Thermal analysis by DTA-TG confirmed a normal pyrophyllite $(\mathrm{PyH})$ and the overlapping of thermal effects of other silicates mixed with pyrophyllite (ZS), in particular the detection of an exothermic effect at $985{ }^{\circ} \mathrm{C}$ only associated to metakaolinite thermal decomposition.

From X-ray results, it can be deduced that heating pyrophyllite produces the formation of a crystal structure of dehydroxilated pyrophyllite, in contrast with kaolinite after dehydroxilation, which remained up to $1200{ }^{\circ} \mathrm{C}$ when mullite is formed with crystallization at $1215^{\circ} \mathrm{C}$. Cristobalite crystallizes at 1325 ${ }^{\circ} \mathrm{C}$ from amorphous silica produced in the previous thermal decomposition. From thermal experiments, it is concluded that prolonged heating treatments favour the formation of the new crystalline phases at lower temperatures, indicating the existence of important kinetic effects in the thermal decomposition of pyrophyllite. In sample ZS, mullite nucleated after the formation of the sharp exothermic DTA effect at $985^{\circ} \mathrm{C}$. When temperature increases, dehydroxilated pyrophyllite disappeared progressively and is not detected at $1200^{\circ} \mathrm{C}$, with an increase of mullite $\mathrm{X}$-ray intensities.In sample ZS, mullite is produced from thermal decomposition of dehydroxilated mica (sericite) and pyrophyllite, and (meta) kaolinite. The formation of mullite and cristobalite in sample ZS occurs at lower temperatures as compared with $\mathrm{PyH}$ sample. After mullite formation, their patterns shows a constancy with temperature, in contrast with cristobalite that disappears above $1300{ }^{\circ} \mathrm{C}$. Cristobalite is appreciated from X-ray diffraction in sample ZS after heating at $1200{ }^{\circ} \mathrm{C}$ or increasing heating time, which nucleates previously by thermal treatment and crystallization from amorphous silica, in contrast with $\mathrm{PyH}$ sample. Sintered materials can be obtained by firing at $1200-1300{ }^{\circ} \mathrm{C}$, with highmullite content and good mechanical strength and practically without cristobalite.

The raw pyrophyllite materials are altered under laboratory conditions using mechanical treatments by dry grinding. Effects are produced on the structure and properties of the solid submitted to grinding or mechanochemical changes, which are induced by dry grinding due to the increase of reactivity of the system. In general, grinding leads to a progressive 
la muestra PyH y ca. $40 \mathrm{~m}^{2} / \mathrm{g}$ en la ZS. Por encima de 30 minutos de molienda, las partículas comienzan a reagregarse y aglomerarse por un proceso de "soldadura en frío" debido al aumento de energía superficial y reactividad de los polvos molidos, lo que coincide con un alto grado de degradación estructural y un aumento de la amorfización, como sucede en otros sólidos por molienda. Un valor mínimo de $7.04 \mathrm{~m}^{2} / \mathrm{g}$ se alcanza después de 325 minutos de molienda en la muestra $\mathrm{PyH}$ y de $8.4 \mathrm{~m}^{2} / \mathrm{g}$ después de 240 minutos en la ZS.

La molienda puede combinarse con un tratamiento térmico que produce un mayor incremento de la reactividad con formación de las fases cristalinas de alta temperatura (mullita y cristobalita) a temperaturas más bajas que en las muestras sin moler con ahorro energético. Los resultados se han comparado teniendo en cuenta las transformaciones térmicas que se producen de caolinita a mullita y el proceso de molienda de la primera bajo las mismas condiciones experimentales que en materias primas con pirofilita $(\mathrm{PyH})$ y en mezcla de ésta con caolinita (ZS). Se producen cambios importantes en la forma de las curvas de ATD-TG correspondientes a las muestras molidas, con pérdidas de peso (agua de hidratación y estructural) a temperaturas más bajas que en las muestras sin moler al aumentar el tiempo de molienda, con la deshidroxilación de los silicatos presentes a temperaturas de $510{ }^{\circ} \mathrm{C}$. La disminución del tamaño de las partículas de los silicatos laminares por molienda y el aumento de la superficie específica que se registra contribuyen a este comportamiento. Un aspecto muy importante es la formación y desarrollo de un efecto exotérmico de ATD a $1000{ }^{\circ} \mathrm{C}$ que no es característico de la pirofilita original. Este efecto aumenta en altura e intensidad (áreas de pico) al aumentar el tiempo de molienda y se asocia a la formación de mullita a por tratamientos mecánicos y térmicos combinados a temperaturas más bajas que en la muestra original. En la muestra ZS, un proceso similar al descrito tiene lugar, aunque en este caso el aumento en intensidad del efecto exotérmico se asocia sólo a la presencia de pirofilita en la mezcla con caolinita y mica, independientemente del contenido de éstos dos últimos silicatos de aluminio, al menos hasta 325 minutos de molienda en seco bajo las mismas condiciones experimentales. La formación de un intenso efecto exotérmico en las curvas de ATD de materiales con pirofilita previamente molidos se asocia, asimismo, a un cambio en la coordinación del Al con liberación de energía y segregación de sílice amorfa, como sucede en la caolinita sometida sólo a tratamiento térmico (12). Esta sílice amorfa cristalizará después como cristobalita al elevar la temperatura.

Se concluye, asimismo, que la formación de fase espinela no es posible en la pirofilita pura mediante tratamiento térmico y tampoco por tratamientos combinados mecánicos, por molienda en seco, y térmicos de acuerdo con los resultados obtenidos y su comparación en el caso de encontrarse presente caolinita $(9,12,35)$. Por último, debe indicarse que estas investigaciones son de gran interés para un mejor conocimiento del mecanismo de alteración de silicatos laminares por activación mecánica, empleando molienda en seco, que se llevan a cabo en el laboratorio y la industria, en particular las materias primas con pirofilita Esto es de interés para la aplicación posterior de los polvos molidos como materias primas cerámicas. destruction of the original crystal structure of the present layered silicates, but it is preferentially produced along the " $c$ " axis or pronounced propensity towards cleavage perpendicular to one crystalline axis. Consequently, the basal $00 \mathrm{l}$ reflections alterated faster than the general ones. The structure of pyrophyllite is completely degraded above 60 minutes. The 110 reflection of pyrophyllite persits above 30 minutes of dry grinding and higher, and lastly disappears with destruction of layered shape of the silicates present in the samples, with amorphization and formation of round irregular aggregates progressively denser, as confirmed by SEM. In sample ZS, it can be seen the degradation of crystalline structures of mica (sericite), kaolinite and, lastly, pyrophyllite in this sequence. Considering the crystal structures of kaolinite (1:1 layer silicate) and pyrophyllite (2:1 layer silicate), it can be concluded that pyrophyllite, with two tetrahedral silica layers would be more difficult to alter by grinding as compared with kaolinite (1:1) under the same experimental conditions.

The increase of surface area of $\mathrm{PyH}$ sample with grinding is interpreted due to a diminution of particle size as a consequence of this treatment up to reach a limit of mechanochemical reduction (ca. $100 \mathrm{~A}$ after 30 minutes), with a maximum value of surface area of $60 \mathrm{~m}^{2} / \mathrm{g}$ in PyH and ca. $40 \mathrm{~m}^{2} / \mathrm{g}$ in ZS sample. Above 30 minutes of grinding time, the particles start to reaggregate and agglomerate by a "cold-welding" process due to the high and enhanced surface reactivity of the ground powders, which coincides with the strong structural alteration and amorphization, as occurs grinding other solids. A minimum value of $7.04 \mathrm{~m}^{2} / \mathrm{g}$ is reached after 325 minutes in $\mathrm{PyH}$ and $8.4 \mathrm{~m}^{2} / \mathrm{g}$ after 240 minutes in ZS.

The grinding treatment can be combined with a subsequent thermal treatment that enhances the increase of reactivity, producing the formation of crystalline phases (mullite and cristobalite) at lower temperatures that in unground samples with energy saving. The results are compared taking into account the thermal transformation of kaolinite to mullite and the process of grinding kaolinite under the same experimental conditions because this layer silicate is present in the raw materials containing pyrophyllite.

Grinding produces important changes in the shape of DTATG diagrams of ground samples with weight loss (water) at lower temperatures than in unground samples as increasing grinding time, with structural dehydroxilation as low as 510 ${ }^{\circ} \mathrm{C}$. The diminution of particle size of the layer silicate by grinding and the increase of surface areas contribute to that behaviour. An importan aspect is the formation and development of an exothermic DTA effect at $1000{ }^{\circ} \mathrm{C}$ that is not characteristic of unground pyrophyllite. This effect increases in intensity (peak areas) and height as increasing grinding time and is associated to mullite formation by combined mechanical and thermal treatments at lower temperatures than in unground pyrophyllite. In sample ZS, a similar process as described above is produced, although the increase in intensity of the exothermic is only associated to the presence of pyrophyllite in this natural mixture, irrespective of kaolinite and mica present in the samples, at least up to 325 minutes of dry grinding under the same experimental conditions. The formation of an intense DTA exothermic peak in ground and heated pyrophyllite samples is associated to a change in $\mathrm{Al}$ coordination with a release of energy and previous segregation of amorphous silica, as occurs in a similar way after heating unground kaolinite (12). This amorphous silica will crystallize as cristobalite by further heating. 


\section{AGRADECIMIENTOS}

Se agradece la ayuda económica recibida dentro del Proyecto de referencia MAT96-0507 que ha hecho posible realizar parte de las investigaciones descritas en este trabajo y la invitación a participar en este número especial del Boletín con la presente contribución.

\section{BIBLIOGRAFÍA / REFERENCES}

1. P.J. Sánchez Soto, J.L. Pérez Rodríguez, “Características generales, propiedades, yacimientos y aplicaciones de pirofilita. I: Estructura, síntesis y características térmicas", Bol. Soc. Esp. Ceram. Vidr., 37, 285-289 (1998).

2. P.J. Sánchez Soto, J.L. Pérez Rodríguez, "Características generales, propiedades, yacimientos y aplicaciones de pirofilita. II: Yacimientos, aplicaciones y utilización como materia prima cerámica", Bol. Soc. Esp. Ceram. Vidr., 37, 359-368 (1998).

3. J. Espinosa de los Monteros, D. Alvarez Estrada, J. Morales Poyato, M.A. del Río Sánchez, "Arcillas sericíticas: nuevas materias primas cerámicas", Bol. Soc. Esp. Ceram. Vidr. 17, 73-78 (1978)

4. E. Galán Huertos, "Posibilidades de utilización de materias primas españolas en la fabricación de refractarios silicoaluminosos y de alta alúmina", Bol. Soc. Esp. Ceram. Vidr. 20, 33-39 (1981)

5. J.M. Mesa López-Colmenar, "Materias primas cerámicas de la provincia de Badajoz: Geología, Mineralogía y Aplicaciones", p. 6-31 en "Los materiales cerámicos y vítreos en Extremadura", Editor Científico J.M. Rincón, Ed. UNED Mérida e Instituto de Cerámica y Vidrio, Mérida 1988.

6. P.J. Sánchez Soto, A. Justo Erbez, M.C. Jiménez de Haro, J.L. Pérez Rodríguez, M. Raigón Pichardo, J. Pascual Cosp, "Caracterización y propiedades cerámicas de una pizarra alumínica que contiene pirofilita", Bol. Soc. Esp. Ceram. Vidr. 33, 199-205 (1994).

7. I.J. Lin, S. Nadiv, "Review of the phase transformation and synthesis of inorganic solids by mechanical treatment (mechanochemical reactions)", Mater. Sci. Eng. 39, 193-214 (1979).

8. V.V. Boldyrev, "Mechanochemistry of inorganic solids", Thermochimica Acta 110, 303-317 (1987).

9. J.A. Pask, A.P. Tomsia, “Formation of mullite from sol-gel mixtures and kaolinite", J. Am. Ceram. Soc. 74, 2367-2373 (1991).

10. J.L. Pérez-Rodríguez, C. Maqueda, A. Justo, "Pyrophyllite determination in mineral mixtures", Clays Clay Miner. 33, 563-566 (1985).

11. J.S. Moya, C.J. Serna, Iglesias J.E., “On the formation of mullite from kandites" J. Mater. Sci. 20, 32-36 (1985).

12. J. Sanz, A. Madani, J.M. Serratosa, J.S. Moya, S. de Aza, “Aluminum-27 and silicon-29 magic-angle spinning nuclear magnetic resonance study of the kaolinite-mullite transformation", J. Am. Ceram. Soc. 71, C418-C421 (1988).

13. R.C. Mackenzie, “Differential Thermal Analysis" Vol.1, p.775, Academic Press, Londres, 1970.

14. a) P.J. Sánchez-Soto, J.L. Pérez-Rodríguez, “Thermal analysis of pyrophyllite transformations", Thermochimica Acta 138, 267-276 (1989); b) P.J. Sánchez-Soto, J.L. Pérez-Rodríguez, "SEM study of pyrophyllite high-temperature transformations", J. Mater. Sci. 24, 3774-3778 (1989).

15. P.J. Sánchez-Soto, I. Sobrados, J. Sanz, J.L. Pérez-Rodríguez, "29-Si and 27-Al magic-angle spinning nuclear magnetic resonance study of the thermal transformations of pyrophyllite", J. Am. Ceram. Soc. 76, 3024-3028 (1993).

16. K.J.D. MacKenzie, I.W.D. Brown, R.H. Meinhold, M.E. Bowden, "Thermal reactions of pyrophyllite studied by high-resolution solid-state $27-\mathrm{Al}$ and $29-\mathrm{Si}$ nuclear megnatic resonance spectroscopy", J. Am. Ceram. Soc. 68, 266-272 (1985).

17. P.J. Sánchez-Soto, J.L. Pérez-Rodríguez, "Formation of mullite from pyrophyllite by mechanical and thermal treatments", J. Am. Ceram. Soc. 72, 154-157 (1989).

18. K.C. Rieger, “What raw materials can do to cut energy comsumption?", Ceram. Eng. Sci. Proc. 1, 842-847 (1980).

19. B. Cicel, G. Kranz, "Mechanism of montmorillonite structure degradation by percussive grinding", Clay Miner. 16, 151-162 (1981).

20. E.F. Aglietti, "The effect of dry grinding on the structure of talc", Appl. Clay Sci. 9, 139-147 (1994).

21. P.J. Sánchez-Soto, J.L. Pérez-Rodríguez, I. Sobrados, J. Sanz, “Influence of grinding in pyrophyllite-mullite thermal transformation assessed by 29Si and 27Al MAS NMR spectroscopies", Chem. Mater. 9, 677-684 (1997).
It is also concluded that the formation of spinel phase is not possible in pure pyrophyllite after thermal treatment, and neither by combined mechanical by dry grinding and thermal treatments according to the present results and those obtained in kaolinite $(9,12,35)$. Finally, it must be pointed out that this research work is of great interest to a better understanding of the mechanism of silicate alteration when intensive mechanical, by dry grinding, and thermal treatments of natural raw mixtures of silicates containing pyrophyllite, are being performed in the laboratory and in industry. These are useful to apply the ground pyrophyllite powders as ceramic raw materials.

\section{ACKNOWLEDGMENTS}

The financial support of DGICYT through the research project referenced MAT96-0507 is gratefully acknowledged to perform part of this study. Thanks are extended to acknowledge the invitation to contribute this special issue with the present paper.

22. J.L. Pérez-Rodríguez, L. Madrid, P.J. Sánchez-Soto, “Effects of dry grinding on pyrophyllite", Clay Miner. 23, 399-410 (1988).

23. P.J. Sánchez-Soto, M. Macías, J.L. Pérez-Rodríguez, "Effects of mechanical treatment on X-ray diffraction line broadening in pyrophyllite", J. Am. Ceram. Soc. 76, 180-184 (1993)

24. S.J. Gregg, "Surface chemistry study of comminuted and compacted solids", Chem. Ind. 11, 611-617 (1968).

25. L. Lü, M.O. Lai, Mechanical Alloying, Kluwer Academic Press, Norwell, Massachussetts, 1998.

26. P.J. Sánchez-Soto, A. Justo, J.L. Pérez-Rodríguez, “Grinding effect on kaolinitepyrophyllite-illite natural mixtures and its influence on mullite formation", J. Mater. Sci. 29, 1276-1283 (1994)

27. P.J. Sánchez-Soto, M.C. Jiménez de Haro, L.A. Pérez-Maqueda, I. Varona, J.L. Pérez-Rodríguez, "Effect of dry grinding on well-crystallized and poorly-crystallized kaolinite", J. Am. Ceram. Soc., aceptado, 2000.

28. F. González García, M. González Rodríguez, C. González Vilchez, M. Raigón Pichardo, "Efectos de la molienda seca sobre un material natural que contienen pirofilita y caolinita", Bol. Soc. Esp. Ceram. Vidr. 31, 297-304 (1992).

29. P.J. Sánchez Soto, “Influencia de los tratamientos mecánicos y térmicos sobre pirofilita y sus efectos en la formación de mullita", Tesis Doctoral, Universidad de Sevilla, 794 pp., Febrero 1990. Resumen publicado en Bol. Soc. Esp. Ceram. Vidr. 29, 431-432 (1990).

30. T.A. Korneva, T.S. Yusupov, "High-temperature behaviour of kaolinite after super-fine grinding", p. 336-339 en Proc. First European Symposium on Thermal Analysis, Heyden. Londres, 1976.

31. E.F. Aglietti, J.M. Porto-López, E. Pereira, "Mechanochemical effects in kaolinite grinding", Int. J. Miner. Process., 16, 125-146 (1986).

32. F. González García, M.T. Ruiz Abrio, M. González Rodríguez, "Effects of dry grinding on two kaolins of different degrees of crystallinity", Clay Miner. 26, 549-565 (1991).

33. S. Milosevic, M. Tomasevic-Canovic, R. Dimitrijevic, M. Petrov, M. Djuricic, "Amorphization of aluminosilicate minerals during micronization process", Am. Ceram. Soc. Bull. 71, 771-775 (1992).

34. G.R. Blair, A.C.D. Chaklader, "Firing vs. reactive hot-pressing", J. Thermal Analysis 4, 311-322 (1971).

35. A.K. Chakravorty, D.K. Ghosh, "Reexamination of the kaolinite-to-mullite reaction series", J. Am. Ceram. Soc. 61, 170-173 (1978).

36. K. Okada, N. Otsuka, J. Ossaka, "Characterization of spinel phase formed in the kaolin-mullite thermal sequence", J. Am. Ceram. Soc. 69, C251-C253 (1986).

37. K. Okada, N. Otsuka, "Characterization of the spinel phase from $\mathrm{SiO}_{2}-\mathrm{Al}_{2} \mathrm{O}_{3}$ xerogels and the formation processes of mullite", J. Am. Ceram. Soc. 69, 652-656 (1986). 